Article

\title{
Statistical Evidence on the Role of Energy Cooperatives for the Energy Transition in European Countries
}

\author{
August Wierling ${ }^{1, * \mathbb{C}}$, Valeria Jana Schwanitz ${ }^{1}{ }^{\mathbb{D}}$, Jan Pedro Zei ${ }^{1}{ }^{1}$, Celine Bout ${ }^{2}$, \\ Chiara Candelise ${ }^{3}$, Winston Gilcrease ${ }^{4}$ and Jay Sterling Gregg ${ }^{2}$ \\ 1 Department of Environmental Sciences, Western Norway University of Applied Sciences, Postbox 7030, \\ 5020 Bergen, Norway; valerias@hvl.no (V.J.S.); jan.zeiss@gmx.de (J.P.Z.) \\ 2 Department of Management Engineering, Technical University of Denmark, Building 426, \\ 2800 Kgs. Lyngby, Denmark; cebou@dtu.dk (C.B.); jsgr@dtu.dk (J.S.G.) \\ 3 IEFE, Centre for Research on Energy \& Environmental Economics \& Policy, Bocconi University, \\ Via Roentgen, 1-20136 Milan, Italy; chiara.candelise@unibocconi.it \\ 4 UNESCO Chair, University of Turin, Via Verdi, 8-10124 Turin, Italy; ggilcrea@unito.it \\ * Correspondence: augustw@hvl.no; Tel.: +47-55-58-58-00
}

Received: 31 July 2018; Accepted: 14 September 2018; Published: 18 September 2018

check for updates

\begin{abstract}
The share of renewable energy is increasing throughout Europe. Yet, little is known about how much can be attributed to different actors, other than those commercially active. This paper provides empirical evidence of activities by energy cooperatives in the field of renewable energy in four different European countries. It draws from a database consisting of 2671 entries, contrasting results from current literature. We find that energy cooperatives are important enablers of the energy transition. However, their role is shrinking in recent years due to a tightening or removal of supportive schemes. We conclude that it is necessary to develop a systematic accounting system to properly track and make visible the contributions by different actors. In turn, this will help to better model the likely speed of Europe's energy transition.
\end{abstract}

Keywords: energy cooperatives; cooperatives; community energy; energy transition; transition; social innovation; local actors; renewable energy; renewable; sustainability

\section{Introduction}

The transition to low carbon energy systems is on its way in Europe: Most countries are on track to achieving their specific 2020 targets and the share of renewable energy in final energy consumption at the European level has crossed 16\% in 2014 [1]. However, there is a debate about how fast this process is going and to what extent it can be further accelerated [2-6]. There are two broad lines of approaching this issue, mainly under the labels of "techno-economic analysis" and the "socio-institutional analysis" [5]. The former, with its emphasis on the difficulty of changing existing energy infrastructures and connected established markets, generally points to longer transition times. Whereas the latter tends to be more optimistic, highlighting opportunities for a broad range of societal actors to be innovative curbing the energy transition beyond historically observed rates of transition. Techno-economic analysis is better quantifiable with the help of energy system models, while socio-institutional analysis poses difficulties for estimating at the aggregated level. The reason for this is due to the case studies that dominate in this field of research and implications aiming at the aggregate level stay qualitative. 
This is the starting point for our quantitative investigation in which we focus on the role of the actor "energy cooperatives" in Europe to support the energy transition. Energy cooperatives are innovative social structures that find collective solutions to problems occurring during transition processes or provide testbeds for adapting low carbon energy technologies to local conditions and needs [7-10]. Various forms of energy cooperatives exist and the energy services they provide are broad, ranging from electricity provision to district heating, IT solutions and energy efficiency consulting. Their organizational structures differ across Europe due to country-specific regulatory frameworks and local needs. However, there are common denominators which clearly distinguish them from established commercial actors in energy markets, such as energy utilities. Common characteristics include the involvement of the wider public (enabling the direct participation and ownership of members), the pursuit of non-commercial benefits (such as the fostering of community spirit) and the motivation to accelerate the transition to sustainable energy systems (e.g., phasing out nuclear power, regaining local ownership and control of energy provision). The role of energy cooperatives in contributing and steering the energy transition is thereby important beyond the expansion of installed capacities, in particular through building acceptance for the necessary changes and through the finding and implementation of creative solutions that benefit the development of local communities. However, the contribution of energy cooperatives to the European energy transition has not yet been estimated at the aggregate level. This paper is the first attempt towards such an estimate. We focus on empirical evidence in selected European countries guided by two main questions:

1. Is there statistical evidence that energy cooperatives are important actors in the energy transition in Europe?

2. What are common reasons that support or hinder activities of energy cooperatives?

This paper aims to answer the above questions using statistical analysis and drawing from evidence provided in various literature. Doing this, we aim to fuel the discussion about developing a systematic accounting for actors of the energy transition beyond those commercially active (see for example [11] on differences between these two general types of actors). Our database of energy cooperatives comprises entries from Austria, Germany, Denmark, and the United Kingdom, totalling 2671 entries. We combine the statistical analysis with the review of case studies. It allows us to draw conclusions at the European and individual country levels on how to support energy cooperatives. To the best of our knowledge, we offer the most comprehensive statistical analysis on energy cooperatives in different European countries to date.

The paper is organized as follows. The next section reviews available literature on cross-country studies of energy cooperatives. Section 3 describes the methodology for building the statistical database. Section 4 presents results for cross-country statistics followed by the presentation of results from the analysis of individual countries. The results will be contrasted with other evidence found in the literature. Section 5 combines all results together to draw conclusions.

\section{Literature Review}

Community activities in energy production and their relevance for the sustainable energy transition have attracted increasing attention in research during the last two decades with a vast body of literature available. However, most of it focuses on single countries or case studies. In this study we specifically focus on organizational structures that can be labeled as "energy cooperatives" (refer to country-specific definitions in the Methods section). Recommended entry points to the literature are $[10,12-14]$. Recent country-specific entry points to the literature are: Germany [10,14], Denmark [15,16], Belgium [17], Sweden [18,19], UK [20], Finland [21], Spain [22], Italy [23], Austria [24,25], France [26], Netherlands [27].

Only 11 publications go beyond the study of single countries [7,11-13,18,19,26,28-31]. Denmark and Germany are the countries most often cited in these comparisons, coinciding with the fact that Denmark has been a pioneer country in the development of energy cooperatives since the 
1970s, while Germany saw a boom in the foundation of energy cooperatives in the aftermath of the Fukushima disaster in 2011. Great Britain and the Netherlands are also focal countries. While energy cooperatives differ in size, strategies and success, the cross-country comparisons clearly document that there are common features among energy cooperatives in Europe. All publications stress the important role of community activities in the transition towards sustainable energy systems. An early example from the literature is [11] who looks at energy cooperatives in Denmark, Canada, the United Kingdom, and Germany. The author emphasizes the collective actions contributing to lowering the costs of renewable energy and to act as multipliers of renewable energy solutions. [12] identifies in addition the benefit of local community development in a study for Germany, United Kingdom and the USA.

However, energy cooperatives continue to rely on governmental support to play a role in liberal markets and against incumbents [7,12,19,29]. Many studies also agree in the identification of common barriers. This includes the lack of knowledge and financial infrastructures as well as a hostile institutional context [26]. Notably, a variety of solutions were found to overcome these barriers and that helped to feed a pool of best practices relevant across countries. However, community initiatives are less likely to be successful if their rationale for action is at odds with the government [29]. A qualitative study [7] on energy cooperatives confirmed the relevance of support instruments for renewables, planning policies, attitudes towards the cooperative model as well as local energy activism on the success and failure of energy cooperatives in Denmark, Germany, Belgium and the United Kingdom. The authors of that study emphasize that energy cooperatives are recently experiencing increased pressure due to changing policies and higher competition in local energy markets. In addition to adapting their activities, energy cooperatives are beginning to react to these challenges by establishing cooperation among single entities (see also [13] on "communities of interest". The authors study community activities in the United Kingdom, Italy, Spain, and Germany.). In addition to the fact that such new networking activities are a response to challenges, it underlines the transformative potential that energy cooperatives possess beyond the local level. [28,31] focus on the role of financial incentives and associated risks. The common finding is that regulatory uncertainty and decreasing financial support strongly undermines the foundation of new and the continued success of existing energy cooperatives.

Finally, an interesting common aspect is put forward in [30]. The authors analyze the influence of historical conditions on the founding of energy cooperatives in Canada and New Zealand. One key element is that many actors seem to belong to groups outside of the main stream (e.g., ethnic minorities). Often the founding of cooperatives by these groups coincides with a lack of awareness by the political establishment in these countries. Similar parallels can be drawn to European countries in that pioneers of energy cooperatives are also often built by societal groups that aim to demonstrate alternatives to established socio-political structures (e.g., anti-nuclear movement in Germany).

\section{Methods}

Our statistical analysis focuses on Germany, Denmark, the United Kingdom and Austria. Besides Austria, all countries are focal countries in the qualitative studies described in Section 2. These countries also have the largest numbers of energy cooperatives in Europe [7], justifying a statistical analysis of these actors. Moreover, these countries provide access to standardized sources of data about energy cooperatives. Good data coverage is also the rationale to include Austria. For each country, we selected those specific legal forms, which come closest to the concept of an energy cooperative (see specific definitions below). It is important to stress that we are far from providing a comprehensive accounting for energy cooperatives in the European union. However, capturing focal countries and well-known regulatory frameworks in each of them, we are able to provide a profound lower estimate for the aggregate contribution of energy cooperatives in Europe. 
We generated a multi-country database of energy cooperatives which contains 282 entries for Austria, 1109 entries for Denmark, 965 entries for Germany, and 315 entries for the United Kingdom. The database has been constructed from accessing national official registries of energy cooperatives that typically detail the date of foundation (and cancellation), their addresses and sources for further information. We searched for registered cooperatives active in the field of renewable energy to build an initial list [32-38]. We extended entries for further information on member statistics, finances, and the evolution of cooperatives.

Table 1 provides methodological details for each of the countries and sources of information. In addition to the main registries shown, we also collected information on single cooperatives from self-profiling websites, discussion forums, newspaper articles etc. In cases of deleted energy cooperatives, we further accessed archived webpages available from archive.org. Since the availability of open data on cooperatives varies from country to country due to legislative differences and the amount of voluntary information provided by cooperatives, it was not possible to obtain the same level of detail for all countries and all entries. However, we have a complete set of data for all countries for the date of foundation, cancellation and location of each cooperative. Furthermore, for each country, the basic data set could be extended further, which led to our choice of analysis foci for each country. Firstly, for Denmark we were able to collect detailed data on membership (including type and residence of members), secondly, for Germany the field of activities, evolution of membership and financial shares and, thirdly, for United Kingdom the evolution of financial resources. For the sake of a concise paper, we only briefly cover Austria.

In order to ensure high quality data, we have verified the statistical information on single cooperatives with different sources of information wherever possible. For example, regarding cooperatives from the United Kingdom the list of societies has been compared with a recent review by coops.uk [39]. For the final creation of database entries, we further applied the four-eyes principle checking for typos, duplicate data and completeness of entries. 
Table 1. Energy cooperatives included in the database: Overview on methods of search, sources and information collected.

\begin{tabular}{|c|c|c|c|}
\hline Definition of Cooperative & Main Sources of Information & Search Terms & Information Collected \\
\hline \multicolumn{4}{|c|}{ Austria (282)—Focus on Case Studies (Default) } \\
\hline eingetragene Genossenschaft & $\begin{array}{l}\text { Compass Verlag Gmbh (firmeninfo.at), } \\
\text { Firmen ABC Marketing GmbH } \\
\text { (firmenabc.at), HEROLD Business Data } \\
\text { GmbH (herold.at) }\end{array}$ & $\begin{array}{l}\text { Wärmeversorgung, Elektrizität, Kraftwerk, } \\
\text { Solar, Sonne, PV, Photovoltaik, Energie, } \\
\text { Windkraft, Wasserkraft }\end{array}$ & $\begin{array}{l}\text { addresses, dates of incorporation/cancellation, } \\
\text { type of activities }\end{array}$ \\
\hline \multicolumn{4}{|c|}{ Denmark (1109)—Default Focus, Statistical Focus on Membership } \\
\hline Interessentskap & $\begin{array}{l}\text { Central Business Register } \\
\text { (datacvr.virk.dk), Danish Energy } \\
\text { Agency (ens.dk) }\end{array}$ & vindmøllelaug, møllelaug & $\begin{array}{l}\text { addresses, dates of foundation/cancellation, } \\
\text { type of activity, geographic information on } \\
\text { members (incl. type and residence of member), } \\
\text { local production capacities from wind }\end{array}$ \\
\hline \multicolumn{4}{|c|}{ Germany (965) —Default Focus, Statistical Focus on Activities and Membership Dynamics } \\
\hline Genossenschaft & $\begin{array}{l}\text { Trade Registry (handelsregister.de), } \\
\text { Business Registry } \\
\text { (unternehmensregister.de) }\end{array}$ & $\begin{array}{l}\text { Energie, Bürgerenergie, Energiegenossenschaft, } \\
\text { Wasserkraft, Windkraft, } \\
\text { Elektrizitätsversorgung, Energieversorgung, } \\
\text { Strom, Solarstrom, Sonnenstrom, Kraftwerk, } \\
\text { Windenergie, Windpark, Solarpark, PV, } \\
\text { Photovoltaik, Wasserkraft }\end{array}$ & $\begin{array}{l}\text { addresses, dates of foundation/cancellation, } \\
\text { evolution of shares and membership, type of } \\
\text { activities, production capacities (partly) }\end{array}$ \\
\hline \multicolumn{4}{|c|}{ United Kingdom (315)_-Default Focus, Statistical Focus on Finances } \\
\hline $\begin{array}{l}\text { BenCom (registered under } \\
\text { the Co-operative and } \\
\text { Community Benefit Societies } \\
\text { Act 2014) }\end{array}$ & $\begin{array}{l}\text { Financial Conduct Authority } \\
\text { (fca.org.uk), Companies House } \\
\text { (beta.companieshouse.gov.uk) }\end{array}$ & energy, solar, wind, wood, heat and hydro & $\begin{array}{l}\text { date of foundation (cancellation), address, } \\
\text { number of members and amounts raised } \\
\text { (incomplete), } \\
\text { production capacities (incomplete) }\end{array}$ \\
\hline
\end{tabular}




\section{Results and Discussion}

\subsection{Cross-Country Results}

Building on the compiled database as described in the previous section, Figure 1 shows the development of the number of active energy cooperatives in the last four decades for Austria (AUT), Germany (DEU), Denmark (DNK) and Great Britain (GBR). Although our data for Denmark only includes wind energy related cooperatives, the country has very clearly been the pioneer in establishing energy cooperatives in early years and also in absolute numbers. This is remarkable in view of population numbers: AUT-8.4 million, DEU—81.8 million, DNK—5.5 million, and GBR—62.0 million (all are given for 2010).

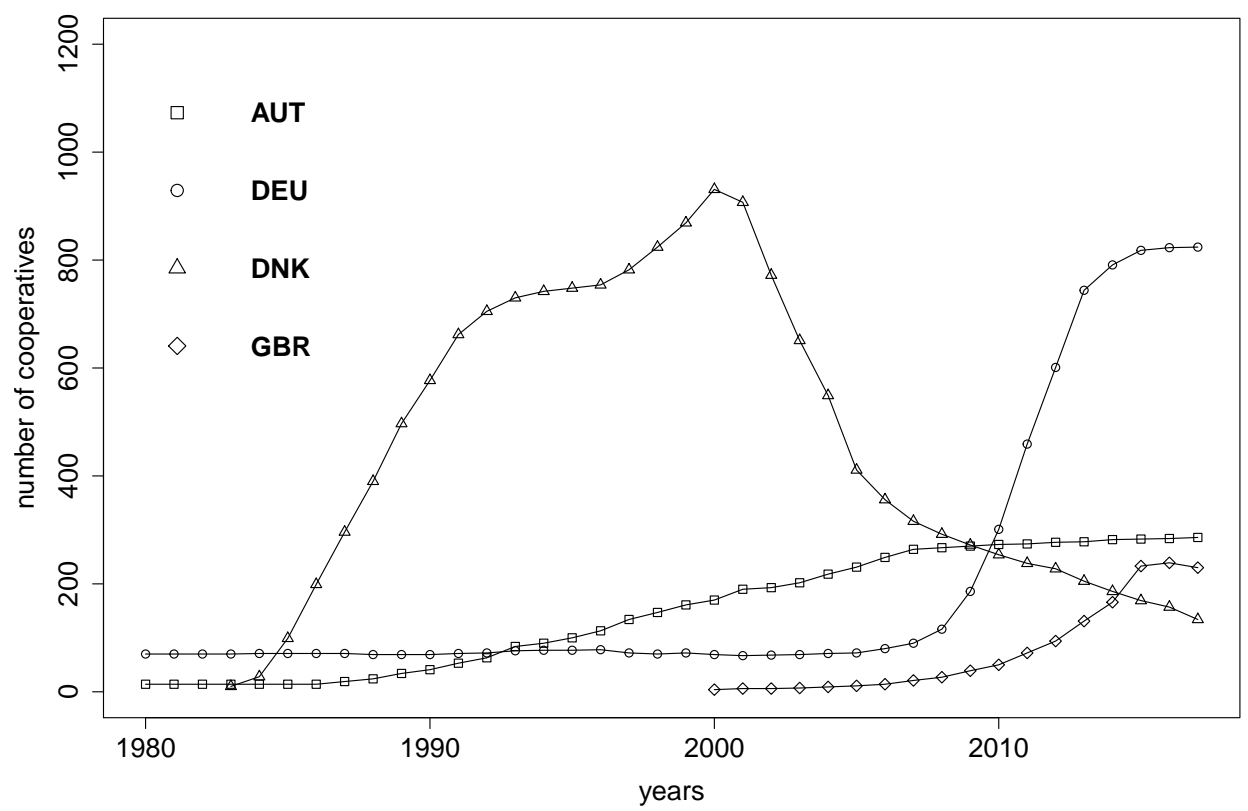

Figure 1. Number of energy cooperatives in Austria (AUT), Germany (DEU), Denmark (DNK) and Great Britain (GBR) for a given year. Source: database compiled by authors, for original sources see Table 1 and methods section.

However, a stark decline in the number of Danish energy cooperatives can be observed from around 2000 onward. As of June 2018, Germany has the largest number of active energy cooperatives with 824, reaching numbers close to Denmark's former peak in 1999 which was at 931 . While the increase in Germany has only taken speed over the past decade, the number of active energy cooperatives is on a slow increase in Austria since the late 1980's and Great Britain since the late 2010. The latest numbers for both are 286 and 230, respectively.

Figure 1 can be compared with a snapshot for 2014 derived from a database owned by the European Federation of Renewable Energy Cooperatives (REScoop.eu), refer to [7]. The network is a sector association of Cooperatives Europe and has currently about 1500 members from the European Union. The 2014 snapshot of the number of cooperatives active in REScoop counts for around 800 energy cooperatives in Germany (in this paper: 791), 650 in Denmark (here: 186), just below 400 in Austria (here: 282), slightly above 100 in Netherlands and Sweden, about 80-90 in Finland and Italy, less than 70 in France and Great Britain (here GBR: 166), between 10-20 in Spain and Belgium, and not more than 5 in Ireland, Portugal, Croatia, Greece and Luxembourg. Germany, Denmark, Austria and Great Britain alone account for about $80 \%$ of the total energy cooperatives in the entire European Union. Differences between the numbers from REScoop and our compilation stem from our focus on specific cooperatives (see definitions in the previous section). For example, we only account for wind energy related cooperatives for Denmark, disregarding cooperatives active in district heating 
or solar. However, in the case of Germany, we came close to the number of REScoop entries. Also tracking cooperatives that have been terminated, we know that those terminated are exceptionally high in Denmark, while rates are more modest in Germany. This may suggest that REScoop did not remove terminated energy cooperatives from its compilation. Furthermore, since the REScoop database is not publicly available, differences can not be fully clarified. On the other hand, considering the development shown in Figure 1, the focus on just four countries for the analysis in this paper is a good representative share of energy cooperatives active in Europe.

Figure 2 presents the share of renewables in total final energy consumption for the four different countries between 1990-2015. Clearly, the shares have been steadily increasing from very low numbers in the 1990's (below 10\%) for all countries except for Austria (25\%), where hydro power traditionally plays an important role. The fastest increase can be reported for Denmark, echoing the early activities of energy cooperatives in the small country. The lowest share number of energy cooperatives was reported in the United Kingdom, with initiatives under 10\% in 2015. Again, this mimics the low numbers in energy cooperatives. The following is an in-depth discussion to better understand energy cooperative developments in several individual European countries.

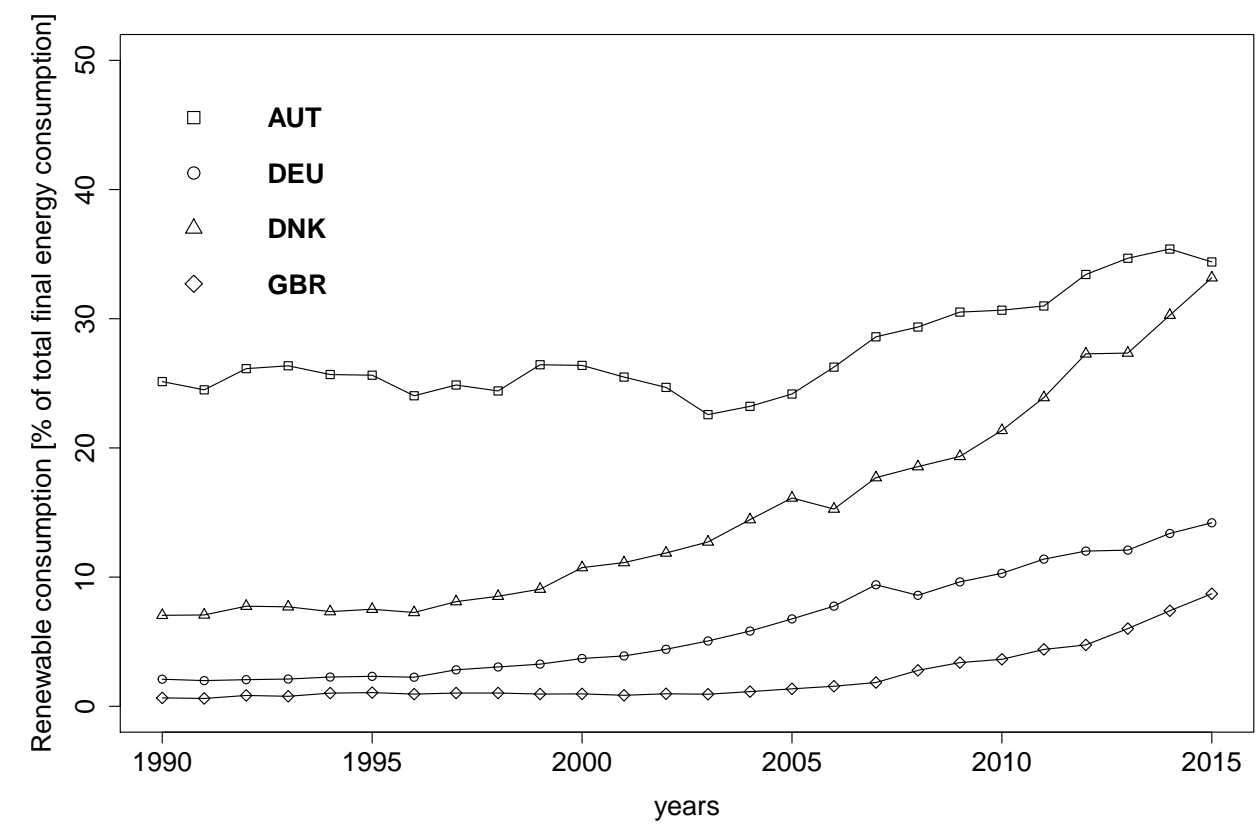

Figure 2. Renewable energy consumption as percentage of total final energy consumption in Austria (AUT), Germany (DEU), Denmark (DNK) and Great Britain (GBR) for a given year. Source: The WorldBank DataBank 2018.

\subsection{Denmark}

Prior to the 1970s oil crisis, Denmark was reliant on imported petroleum for nearly $80 \%$ of its energy needs. After the embargo, Denmark began to shift away from fossil fuels in order to promote energy security [40]. Collective anti-nuclear networks formed the basis for cooperatives [15]. Geographically, Denmark has abundant wind resources, and wind cooperatives were successful in bringing the costs of turbines down and generating public acceptance of renewable energy. By 2017, $49 \%$ of the electricity produced in Denmark originated from wind-based energy; 6214 turbines were in operation as of April 2018 (see also Figure 3 for the development of installed capacities based on data from the Danish Energy Agency [41]). In 2002, energy cooperatives owned about $40 \%$ of the then installed turbines, revealing that energy cooperative initiatives were important for the Danish energy transition [42]. Moreover, 150,000 households participated in wind power cooperatives underlining the great support from the broader society (ibid.). 


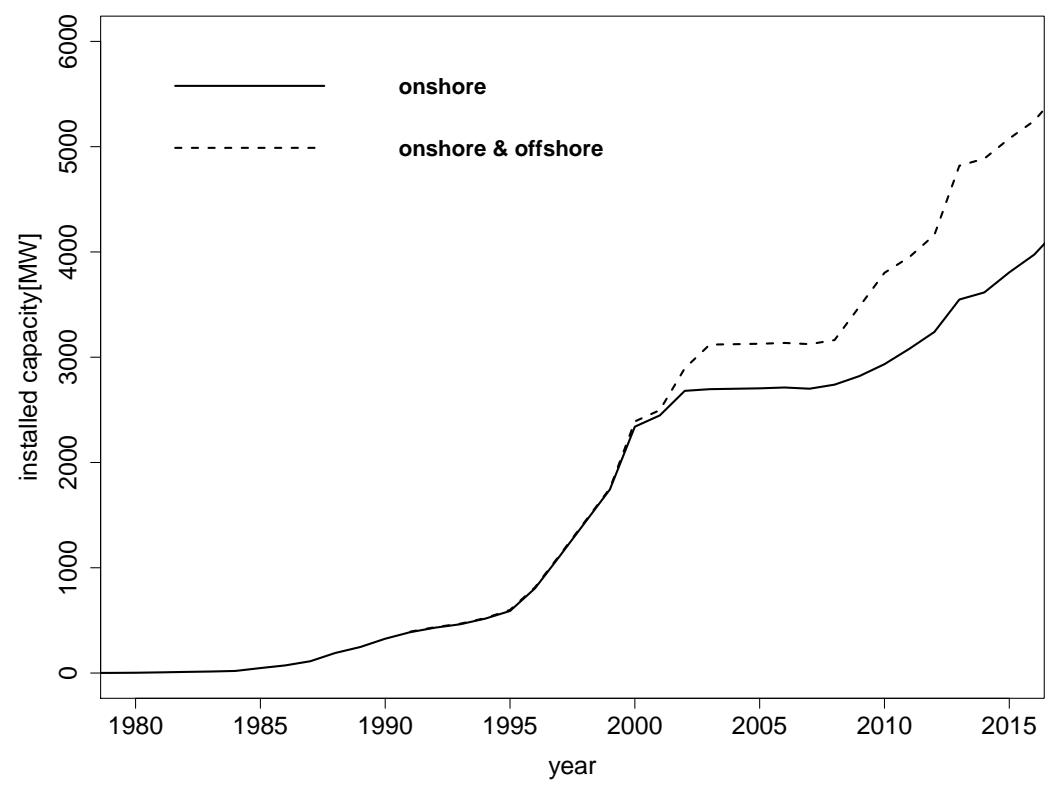

Figure 3. Installed capacity of onshore and offshore wind farms in Denmark. Source of data: [41].

By the 1990s, there was a diminishing role for the collective ownership model, shifting toward more private ownership, typically by farmers [43]. This was supported by a 1992 feed-in tariff program for wind, and guaranteed interconnection and power purchase at a "fair price" at $85 \%$ of retail rates [44]. Additionally, wind projects were eligible for a refund from the Danish carbon tax and a refund on the energy tax, essentially doubling the payment for wind power [45]. In 1999, the Danish parliament ratified the Energy Supply Act, which among other measures, gave customers the freedom to choose their electricity provider and promoted a quota system for renewable energy through certificates. This required consumers to purchase a certain share of renewable energy in order to further establish the market [46].

However, in 2002, the newly elected centre-right Danish parliament announced the end of feed-in tariffs for wind energy. They argued that wind was mature enough as a technology to not warrant further government support and pushed for market liberalization as an attempt to increase competition and lower consumers' electricity costs. The tariff was phased out in 2004, resulting in a substantial decrease in wind energy cooperatives. This suggests that the technology had reached a level of maturity that economies of scale were achieved. This made it economical for larger companies, such as energy service providers, to enter the market. However, this was not the case for existing cooperatives, which owned a smaller number of turbines. These developments coincided with technological improvements and legislative changes that favored larger wind park installations. The size of turbines grew from $55 \mathrm{~kW}$ to $3.3 \mathrm{MW}$ and beyond, and their height doubled. Furthermore, the typical investment size changed from 0.5-0.8 million euro to about 15-22 million euro [47]. These developments marked the start for the sharp turn in support for wind cooperatives in Denmark. This is clearly mirrored in the data.

Our database contains 1109 registered wind energy cooperatives in Denmark (i.e., all windpower-related 'interessentskap' registered under the Danish law). In addition to the development of the number of cooperatives in the last four decades already shown in Figure 1, Figure 4 adds information contrasting the date of foundation with the dates of termination for Danish wind cooperatives. From both figures, it is evident that two waves of foundation can be observed: The first appearing between 1985-1992 and the second between 1998-2002. Afterwards, the majority of energy cooperatives were terminated at an exponential rate. The developments correlate strongly with political decisions made since 2002 which were likely anticipated before enacted. Furthermore, 2003 marked the beginning of the era of commercial offshore wind park investments (refer to Figure 3). Cooperatives that were driving onshore wind developments, were not able to enter the offshore wind markets at the same time. 


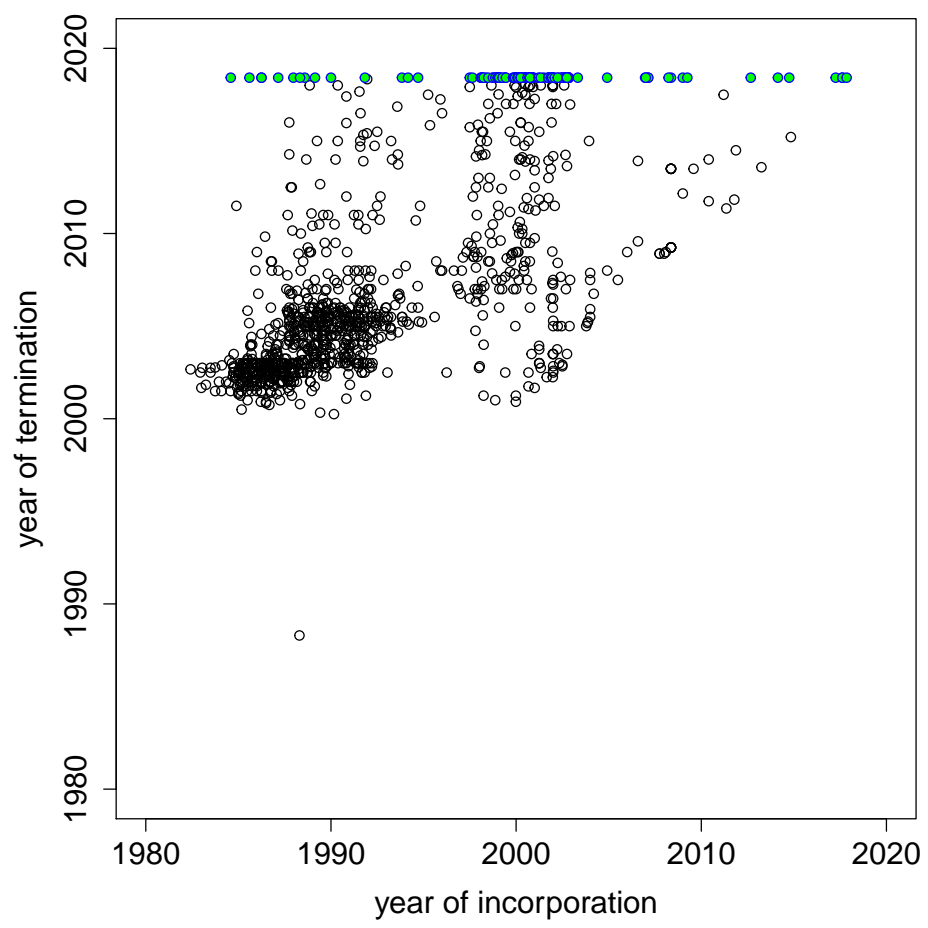

Figure 4. Timing of wind cooperatives in Denmark shown by contrasting the date of foundation with termination dates. Wind energy cooperatives which are still in operation are marked blue, the date of termination is set equal to June 2018. Source of data: own database building on [37].

Today, only $12 \%$ out of the 1109 cooperatives still exist and data indicates a continuation of this trend. Our data are in line with the observation by the Danish Wind Turbine Owners Association, reporting that in 2010 only $15 \%$ of all turbines in Denmark were still owned by cooperatives [48]. While many turbines had reached their end of life, others were also sold to utilities [15]. These firms are also investing in land, often discreetly, and have the advantage of large legal teams to secure their interests [49]. Technologically, it is hard to argue against: large-scale developers are efficient businesses that do a lot investment in land with high wind potential, and the cooperatives have a difficult time competing with these. Obviously cooperatives-the early pioneers of wind development in Denmark - had lost ground. The Danish parliament took note of this development and tried to stimulate local ownership. In 2009, the Danish Renewable Energy Act (DEA) introduced the Option to Purchase wind farm Shares Scheme (OPSS) which stipulated that $20 \%$ of the shares of a new wind project must be available for sale to residents within a $4.5 \mathrm{~km}$ radius of a new wind project (Promotion of New Energy Act, 2009). While a survey-based study has suggested that this has had a positive impact on co-ownership, it has not solved everything in terms of acceptance since it is only aimed at people with sufficient liquidity of funds [50]. Likewise, support for the scheme is largely dependent on demographic variables (ibid). We do not find any response from the OPSS in the data.

We can shed new light into what happened by analyzing the development of membership numbers (i.e., the number of fully liable participants) and the distribution of addresses. Figure 5 shows the percentage of cooperatives sorted into 5 different size classes, with the smallest having only up to 5 members and the largest more than 200. Data for the whole sample of cooperatives are shown as well as the sub-sample of those still existing. In both, small cooperatives dominate. However it is especially the medium-sized cooperatives that disappear. Figure 6 investigates this further by analyzing the percentage of existing cooperatives in different size classes. The majority of the largest cooperatives survived, since only 4 out of 9 have been closed down. However, the smallest size class with up to 5 members and the second-largest size class with 51-200 members lost as much as $85 \%$, even surpassed by the medium size classes with 5-50 members, loosing more than $92 \%$ of the cooperatives. This suggests that smaller- and medium-sized energy cooperatives were unable to survive the trends 
towards larger projects and higher market competition (coinciding with less governmental support) by discontinuing their engagement in the wind energy market.

Figure 7 shows the geographic distribution of energy cooperatives founded in a particular municipality since 1980. Associated shares of the full sample are indicated by different colors. Thisted, a municipality located at the Western coast of Jutland, is the most active municipality in hosting wind cooperatives, with $8 \%$ of the country's share. Overall, most cooperatives were founded in the northwest, while the distribution is rather equal in the rest of the country. The picture is very different today, as can be inferred from Figure 7. The blue diamonds mark the existing wind cooperatives across the 98 Danish municipalities as of June 2018. Those still existing cluster around the northwest, the island Funen and along the border with Germany. Most of the former cooperatives from Falster, Lolland and Zealand disappeared.

The findings from Figure 7 are connected with the decisions on where to place wind turbines. In the 1980s and early 1990s, turbines were placed throughout the landscape and not necessarily in the areas with greatest wind potential. This resulted in a situation where the turbines had a large visual impact on the landscape, with many smaller turbines in sub-optimal locations from the perspective of the national wind potential [51]. To counteract this development, wind planning zones where established in 1995 [51-53]. Also, in 2001 the scrapping schemes were designed to rectify the situation, and municipalities were tasked with planning the siting of wind turbines. They took advantage of the areas with the greatest resource potential while at same time taking into account residential, environmental, cultural, and landscape considerations [51]. Concurrently, Denmark reduced the number of turbines in two waves. During the period from 2001-2004 the numbers went down by 1208, while at the same time, increasing wind power capacity by 202 MW [52]. In the period from 2004-2011, subsidy schemes were installed to incentivize owners of turbines to replace smaller ones $(25 \mathrm{~kW}$ for domestic turbines, $450 \mathrm{~kW}$ for grid connected turbines), for up to $175 \mathrm{MW}$ pooled capacity [54]. Eventually, municipalities tended to favor fewer and larger turbines. Consequently, wind cooperatives disappeared in areas with low wind yields concentrating in others, which is in agreement with data shown in Figure 7. Notably, Thisted is located in the region with the highest wind yields in Denmark.

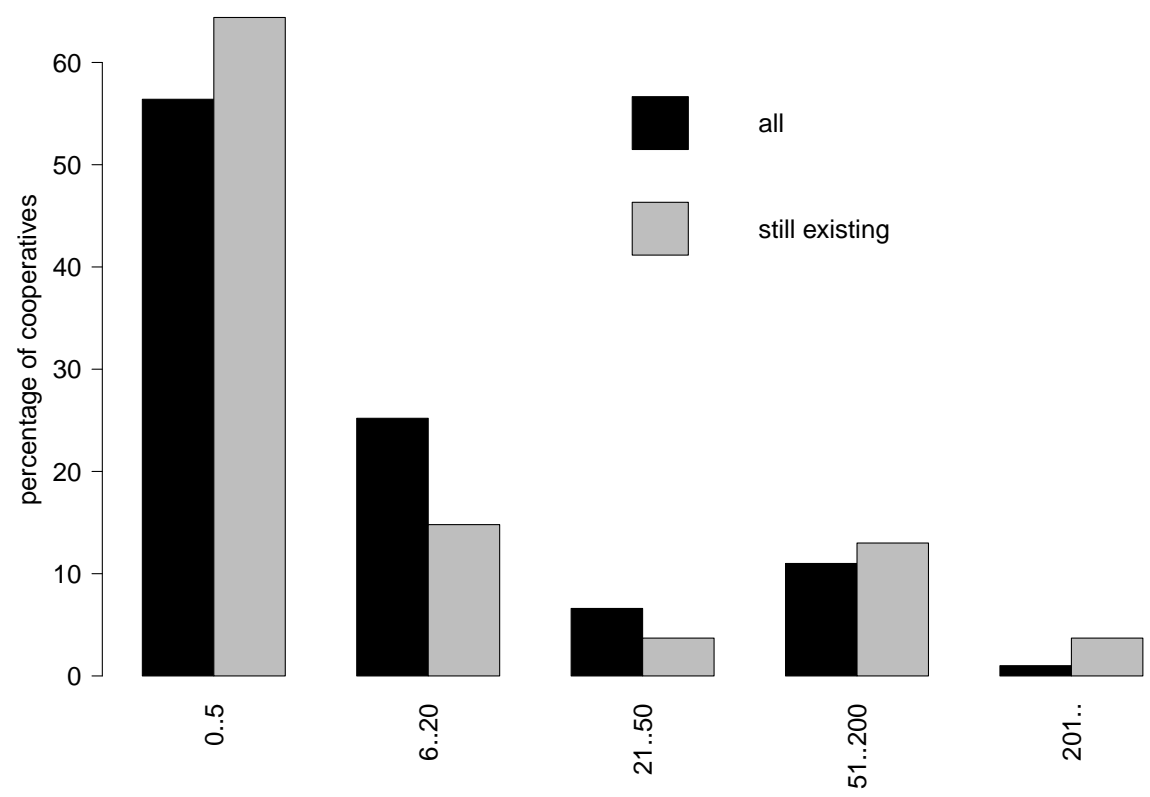

Figure 5. Membership size of wind energy cooperatives in Denmark in five different size classes. Source of data: own database building on [37]. 


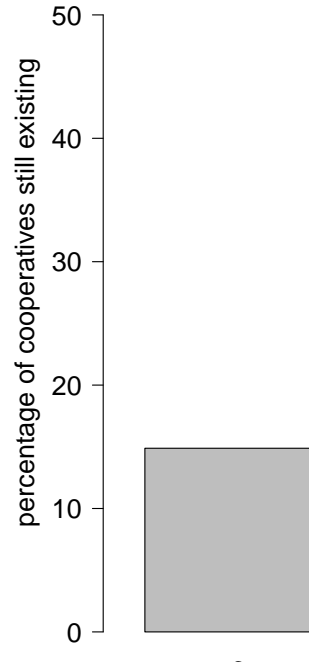

$\stackrel{10}{0}$

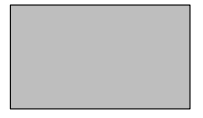

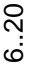

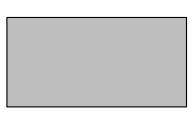

$\stackrel{\substack{n \\:}}{\grave{n}}$

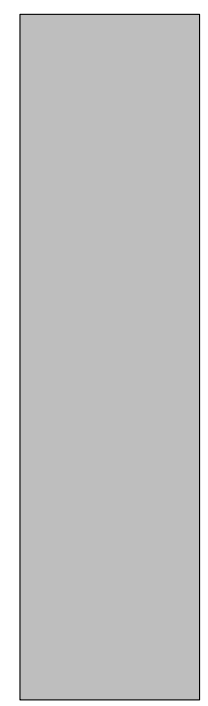

$\dot{\sim}$

Figure 6. Percentage of cooperatives still in operation in five different size classes. Source of data: own database building on [37].
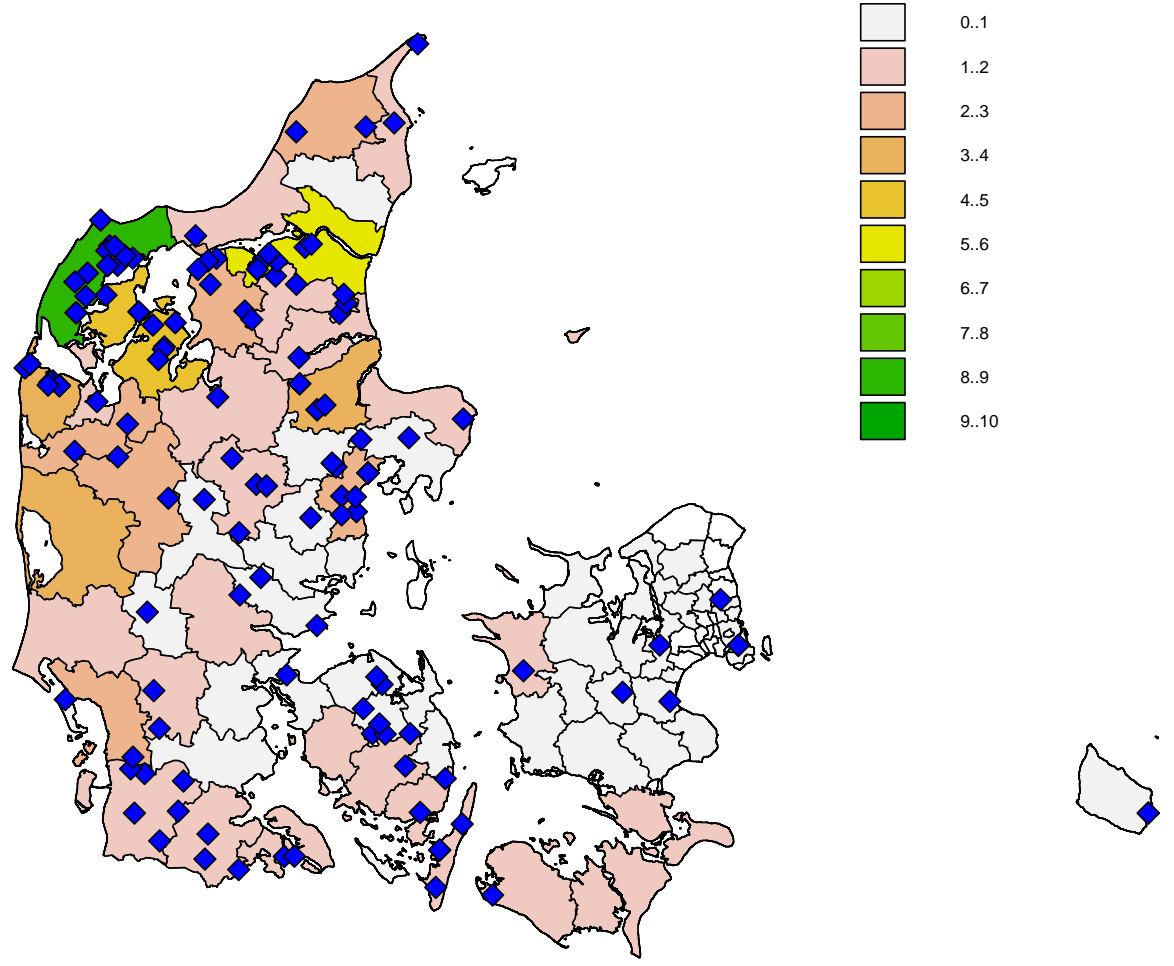

Figure 7. Geographical distribution of existing wind cooperatives (blue diamonds) across the 98 Danish municipalities since 1980. The color coding marks the percentage of energy cooperatives in the full sample (incl. terminated ones) that are associated with a specific municipality. Source of data: own database building on [37].

The role of the early pioneers of the Danish energy transition is likely to become further marginal. Beginning in 2019, onshore will be ruled by tendering processes for all sizes of wind farms, which means that cooperatives will be placed at an even greater disadvantage against large-scale developers. Developers are buying houses to clear out more available land, expecting a return on investment, so 
they are expected to be quite competitive in the tendering process. In interviews, cooperative leaders expressed concern for what this means for the cooperatives on their respective islands, e.g., Samsø and Ærø (personal communication from the authors). To date, these cooperatives have largely been referred to as success stories in providing sustainable energy while generating income to the islands' residents. Few efforts exist to sustain the wind cooperatives in Denmark by providing legal and financial information.

Finally, in the 2018 energy agreement, the Danish government outlines a strategy to further reduce the impact on the landscape and more than halve the number of onshore turbines by 2030, from 4300 to 1850. Furthermore, the provision of new turbines will be dependent on the number of turbines removed. Direct support for household turbines is also discontinued after 2020. This is a clear move away from the cooperative model for wind energy in Denmark.

However, recent research argues that these incentive schemes are at odds with a sustained provision of electricity in a 'high wind future'. Hvelplund et al. (2017) [16] expect that the continued decrease of wind power prices at the spot markets will prevent profitability of wind farms in Denmark. The authors suggest as a countermeasure to push investments into advanced infrastructure, also integrating of the transport sector with wind-to-fuel technologies. Furthermore, local acceptance [50,55] is key for achieving the necessary changes. Here, new opportunities for cooperatives may open up to influence the transition once again.

\subsection{Germany}

Our database encompasses 965 energy cooperatives for Germany, most of which have been established since 2010 (see Figure 1). This development is to a large extent a reaction to the Fukushima Daiichi nuclear disaster in 2011 which led to the decision to phase out nuclear power in Germany by 2022. At the same time it was decided to accelerate the low carbon energy transition, known as "Energiewende". The Renewable Energy Resources Act, which was enacted in the year 2000, has been the key policy, granting fixed feed-in tariffs and priority feed-in for electricity that originates from renewables. This enabled other support mechanisms such as loans and grants at better conditions, leading to the notable growth of energy cooperatives and other forms of citizen-led energy initiatives $[7,11,56-58]$. All of these initiatives contributed $47 \%$ of renewable energy capacities installed by 2012; the share of energy cooperatives was $9 \%$ [59].

Cooperatives, including energy cooperatives, have a long tradition in Germany. Most of the 8100 cooperatives with 21 million members are engaged in the banking and trade sector. It was largely energy cooperatives that were driving the electrification of rural areas in the beginning of the 20th century [60]. Our database contains 72 energy cooperatives that were founded before $1950.70 \%$ of those established during the 1920s (i.e., 27) are still existing today. Cooperatives are organized in the German Cooperative and Raiffeisen Confederation (Deutscher Genossenschafts- und Raiffeisenverband e.V., short: DGRV). This confederation also conducts yearly surveys among its members and publishes reviews and data.

We start by comparing our base data with those published in the most recent survey [61]. As of 2016, we have information about memberships for 601 cooperatives. As much as 197,686 persons are organized in these cooperatives, corresponding to a number claimed by the DGRV which reports 165,000 persons in 2015 (ibid.). The lower number is likely caused by the statistical error due to the low response rate of only $34 \%$ in the DGRV survey. Our mean number of members equals 329 , which again is higher than 221 as reported by DGRV. The number of total shares invested in the cooperatives amounts to 596,383,202 euro, a number which is based on information available from 566 out of the 965 registered energy cooperatives. In comparison, DGRV reported 655 million euro in total capital invested by members, a number comparable to our data.

While the number of energy cooperatives in Germany are similar to Danish cooperatives during the 2000s (see Figure 1), the fields of activities are much broader. $360(60 \%)$ are active in solar PV, $186(31 \%)$ in heat and wood-based renewable energy, 120 (20\%) in onshore wind energy, 90 (15\%) in 
energy trade, $52(9 \%)$ in biogas, $22(4 \%)$ in hydro power, and $46(8 \%)$ engage in consulting. Note that numbers can be higher than $100 \%$ because multiple activities are possible. New fields of activities include the provision of broadband internet access, e-mobility and car sharing. However, the numbers in these new fields are still small. 31 of Germany's energy cooperatives possess their own electricity distribution network. Total numbers of installed capacities are often not available since this information is not required to be reported officially. However, an estimate from 2012 amounts to 6.7 GWh [59].

Although the data underscores the importance of energy cooperatives for Germany's energy transition, the number of newly founded energy cooperatives has declined recently. Klagge and Meister [58] refer to it as the "end of the boom". Our data also confirms this decline in newly founded cooperatives (see the blue markers in Figure 8). However, the observed backward trend in the number of newly founded cooperatives does not necessarily signify a decline in engagement. For many cooperatives in our database, the number of members in existing cooperatives is indeed continuing to increase, albeit the overall slowdown in growth. The red markers in Figure 8 show these rates of membership increase per year for a subsample of 300 cooperatives. The gain in membership peaked in 2013, along with a peak in the growth in assets held by energy cooperatives. The data show that the decline in the growth rates is stronger for the number of cooperatives and less pronounced for membership and assets.

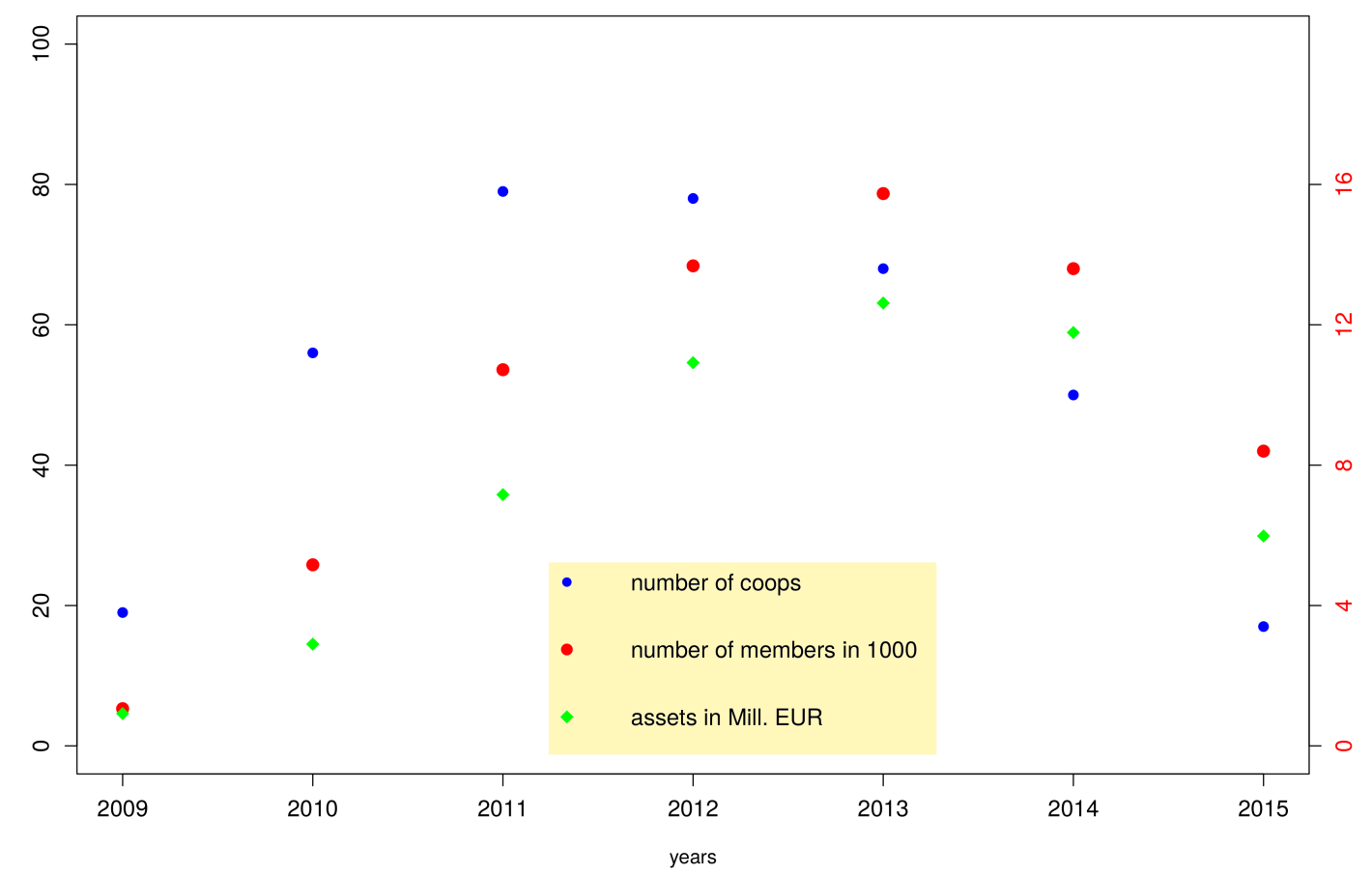

Figure 8. Increase in number of newly founded cooperatives (blue marker) and invested shares (green) - see the axis to the left—and new members (red)—see the axis to the right. Source: own database building on [35,36].

The backward trends strongly coincide with revisions in the Renewable Energy Resources Act in 2012, 2014 and 2017. A central reason for the revision was related to the stability of the electricity grid despite the high penetration rates of fluctuating renewable energies along with rising electricity prices. This led to the introduction of a cap for the prioritized feed-in tariff (FiT) from renewable sources from 2012 onwards. In addition, the FiT schemes were revised in 2014. The latter was discussed as one of the main reasons for the termination of activities [58,61]. The FiT was gradually replaced by a tendering system for most of the renewables, a development also seen in Denmark. As of 2015, the auctioning system was enacted and established 3-4 bidding rounds for solar PV and wind each year. In order to support citizen-led initiatives, small-scale installation are exempted. 
Our database also provides an overview of membership dynamics. Figure 9 shows the evolution of memberships for 495 out of 965 energy cooperatives (normalized to the year 2016). Different types of dynamic patterns can be distinguished. These are indicated by different colors. Red is the group of cooperatives that increase most rapidly in membership, followed by green, blue, and gray. Those indicated in black hardly change in the number of members over the years. As expected, older cooperatives tend to be more stable in size. While most of the cooperatives show a continued increase, few of them declined recently. To investigate whether there is a correlation between the dynamic patterns and the size of the cooperative, Figure 10 plots the average rate of increase in membership size versus the size of the cooperative in 2016. As seen from the figure, the growth in membership is rather independent from the size of a cooperative. Figure 11 shows the relationship between the change in number of members from 2015 to 2016 against the change in the number of shares during the same period. Additionally, the size of the energy cooperative is indicated by the color coding, ranging from light colors signaling small cooperatives to dark blue signaling large cooperatives with 500 members or more. Most of the data are located in the first quadrant indicating a growth in both dimensions. Also note that some of them are growing more than proportionally (see the area in the upper left corner). There is no example found in the lower left area, because new members always have to sign a minimum share in a cooperative.

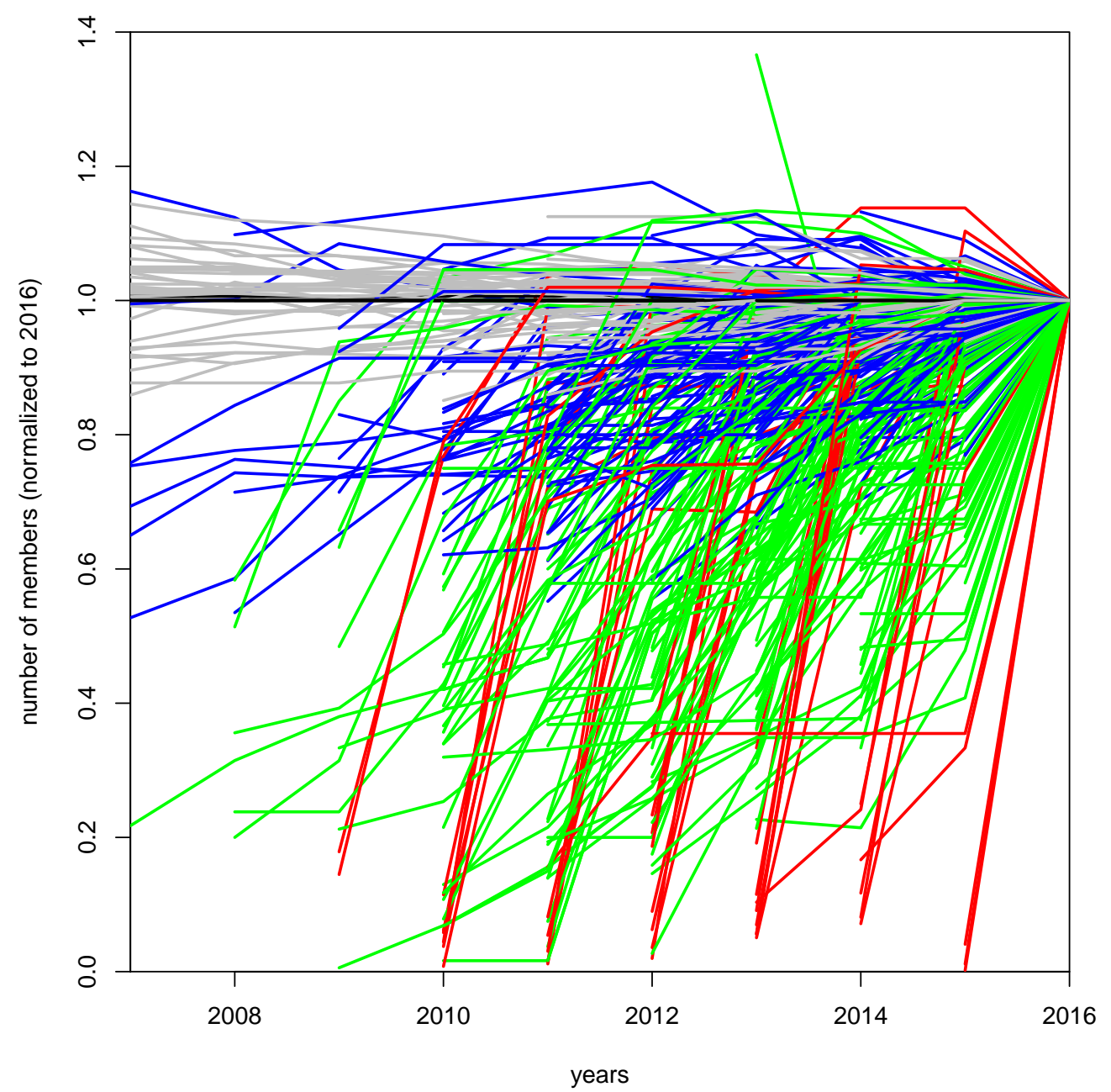

Figure 9. Dynamic patterns of membership among German energy cooperatives. Source: own database building on $[35,36]$.

The number of terminated energy cooperatives amounts to $136(14 \%)$ in our full sample and they are equally distributed over all Federal States of Germany. Analyzing the timing of terminations, we 
find that most were terminated after 2014, refer to Figure 12. There is a clear response to the change in supportive legislation. With the help of data collected from websites, reports and other sources, we can further shed light on the reasons for the termination. We start with reasons that can be considered as a failure of the cooperatives' purpose. The most common were financial reasons, such as the lack of finances to cover unexpected risks and uncertainties due to unanticipated longer project times, higher costs, or difficulty to acquire projects. Others resigned their activities due to unfavorable legislative changes or the inability to raise enough shareholder capital in the beginning. Management problems also contributed to cooperatives' failure, such as disagreements between and within executive boards and members on the future of the cooperative, lack of management capacities or competences as well as insufficient capacity to adapt to new situations. Finally, some of the terminated cooperatives report problems of public acceptance and also the inability to gain significance. Among the reasons for termination that would not be labeled as unsuccessful are fusions or mergers into enterprises or other legal forms as well as changes in location.

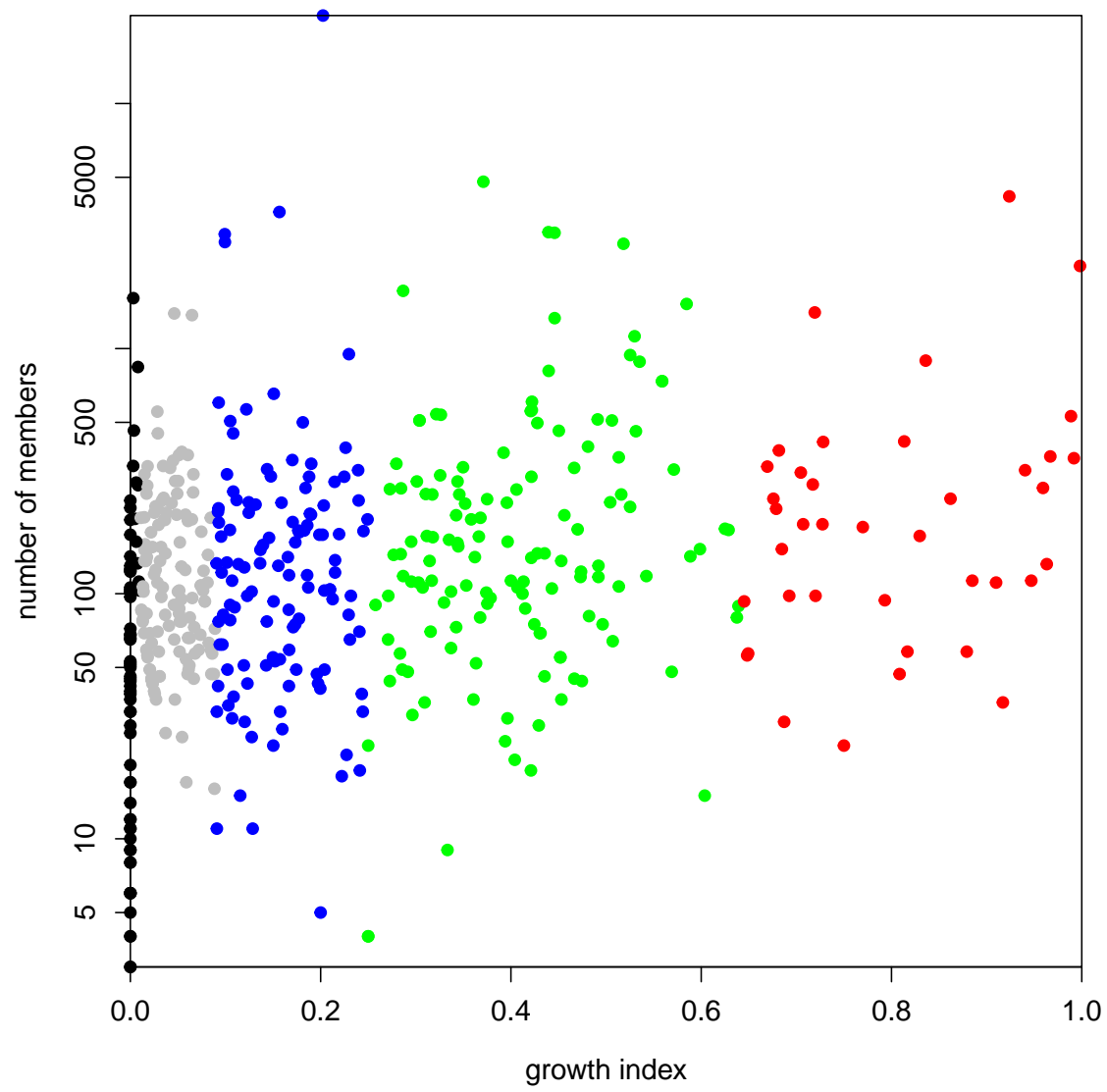

Figure 10. Average rate of increase in membership size versus the size of the cooperative in 2016. Source: own database building on $[35,36]$. 


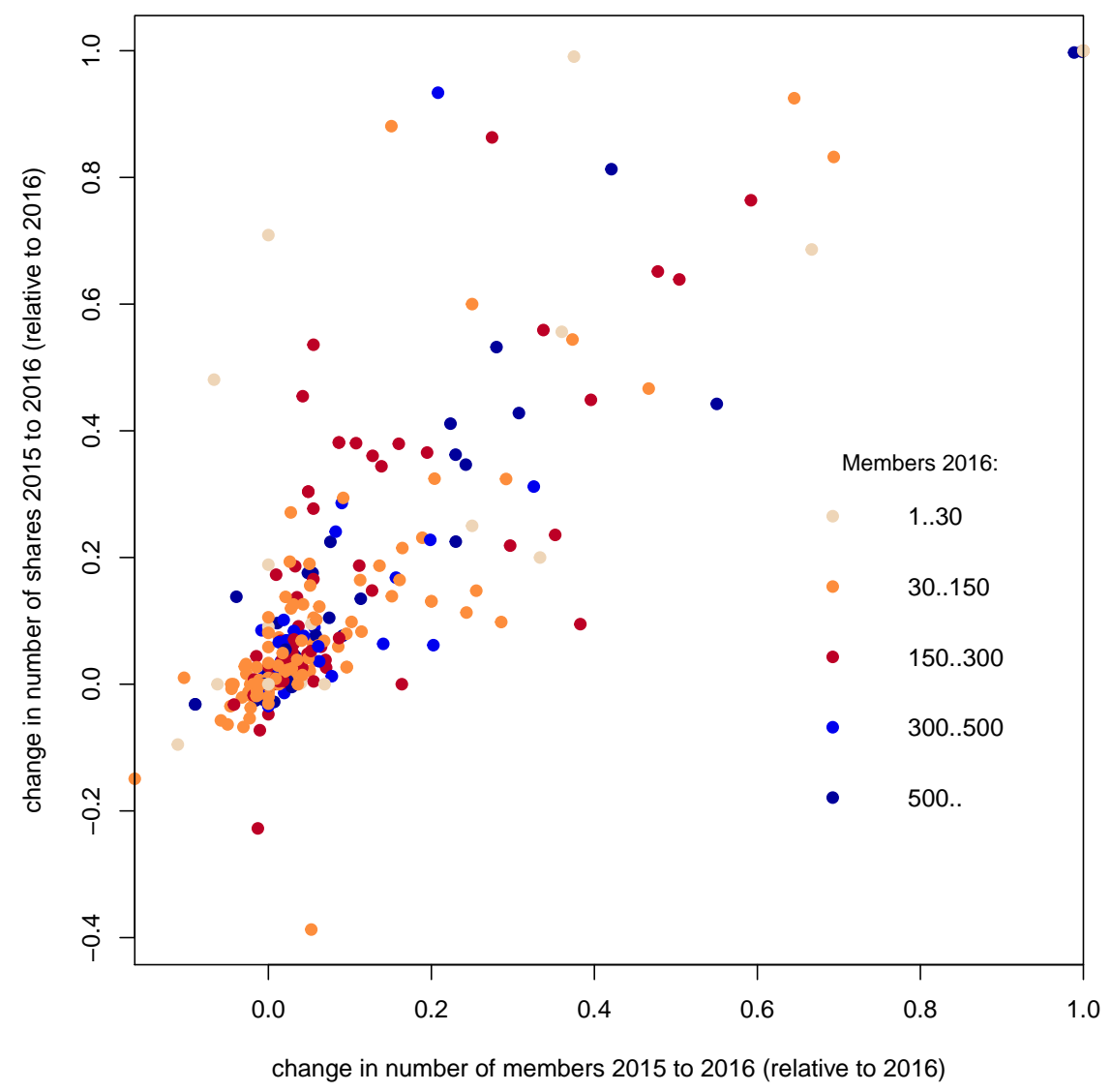

Figure 11. Change in number of members from 2015 to 2016 versus the change in the number of shares during the same period. Source: own database building on $[35,36]$.

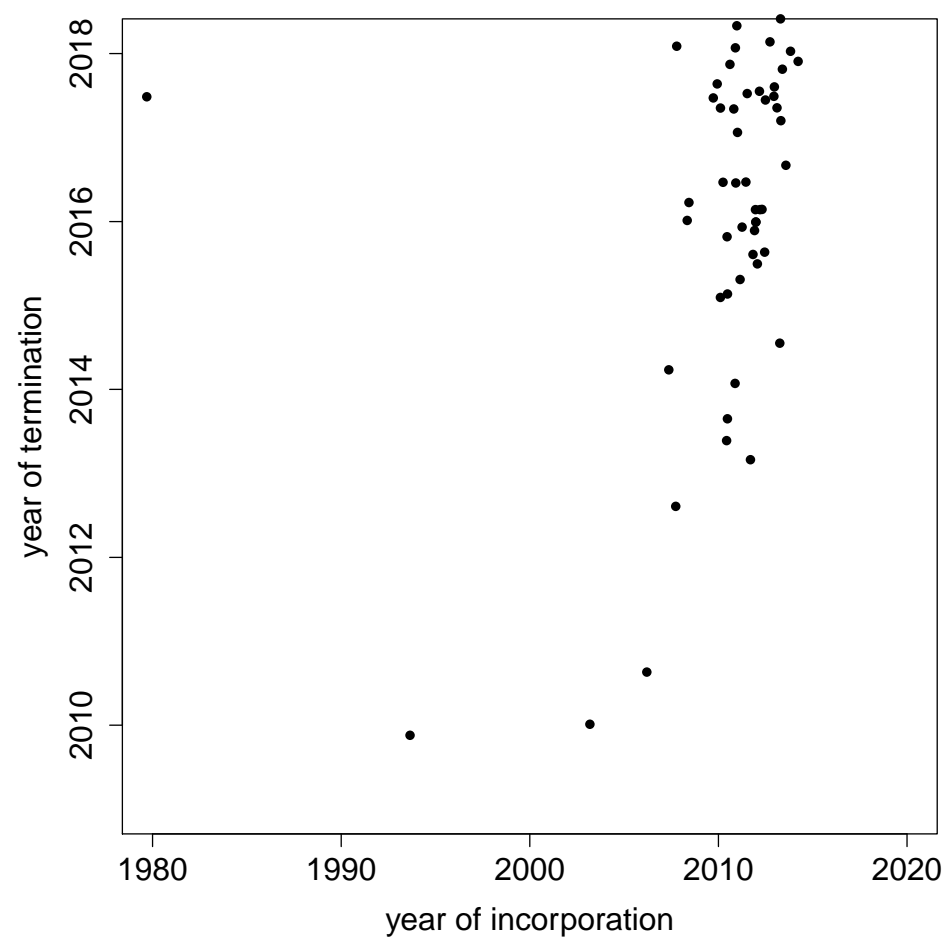

Figure 12. Incorporation dates versus termination dates for closed German cooperatives. Source: Own database building on $[35,36]$. 


\subsection{United Kingdom}

Renewable energy technologies were taken up relatively late in the United Kingdom (UK). In 2014, just $19 \%$ of electricity were generated from renewable energy technologies. This number is 2.8 times higher in Denmark and 1.4 times in Germany [28]. For the scope of this paper, we specifically focus on initiatives that are registered under the Co-operative and Community Benefit Societies Act from 2014 [62]. Initiatives founded in earlier years have been reassessed under these new regulations. The majority of the 315 initiatives that we have collected data from engage in solar PV (40\%), consulting activities $(20 \%)$, hydro power $(16 \%)$, and onshore wind (14\%). Of course, the activities may overlap for each cooperative.

In Figure 13, we present the distribution of the year of establishment for these energy cooperatives. Most were founded in the period between 2010-2015. The increase in energy cooperatives in the United Kingdom coincides with the introduction of feed-in tariffs (FiT) in 2010 [63,64]. The UK FiT scheme has been introduced to support the deployment of small-medium scale renewable energy generation (i.e., below $5 \mathrm{MW}$ ) in addition to the Renewables Obligation (RO) mainly supporting large-scale generation. It has also been introduced with the aim of allowing distributed generation and empowering people by giving them a direct stake in the transition [65]. It has made distributed energy projects more profitable with relatively low risk by allowing stable returns on the investments. Energy cooperatives have thus benefited of such favorable energy policy support. In addition to FiT, community energy initiatives have also been benefiting from the Enterprise Investment Scheme and the Seed Enterprise Investment Scheme tax relieves, which allowed investors to reclaim income tax on their investment at the rate of either $30 \%$ or $50 \%$, respectively. This additional economic benefit comes on top of the predicted interest rate that investors would receive on the investment. Thus, it also played an important role in encouraging green energy investments in the UK.

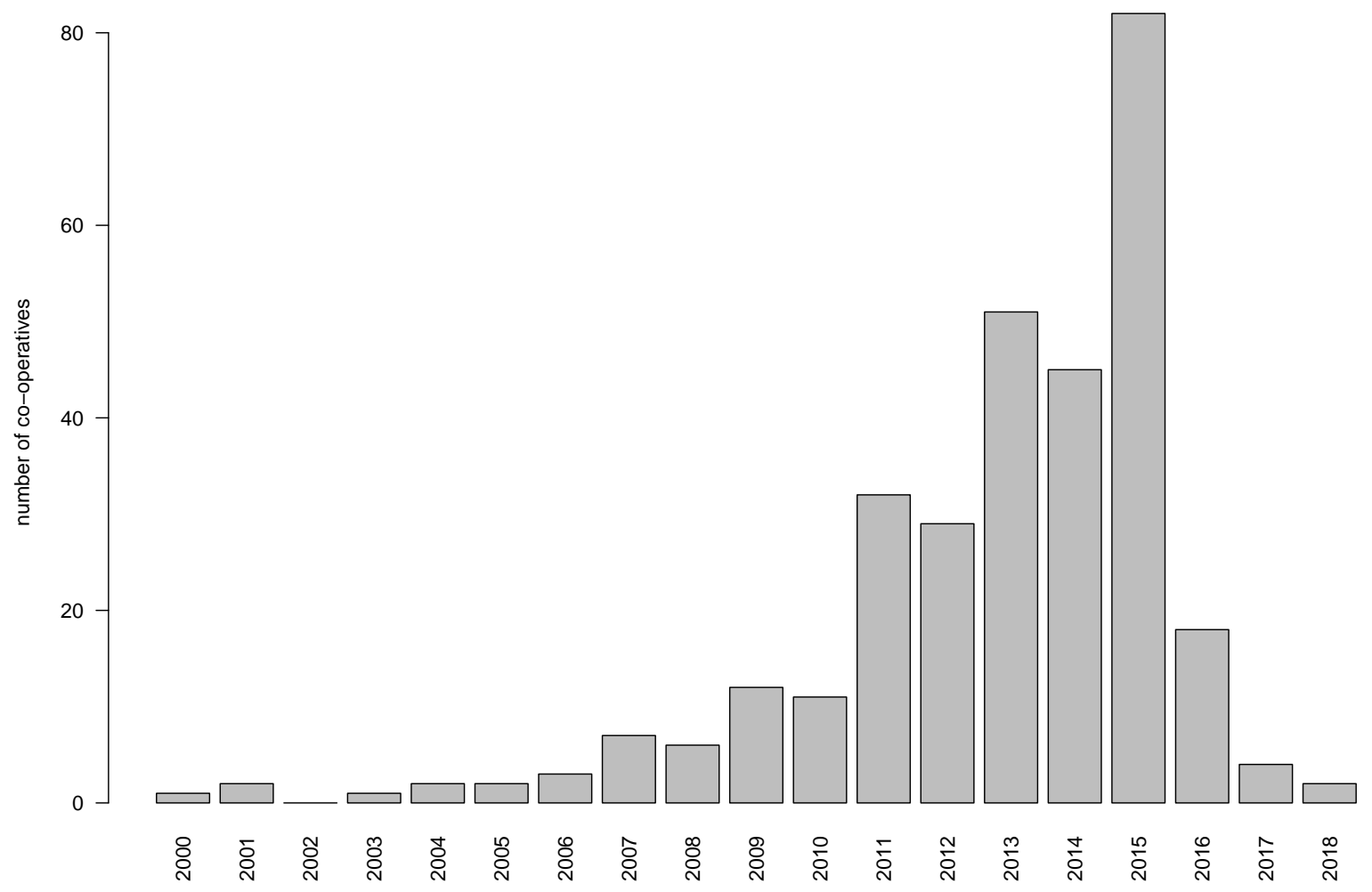

Figure 13. Number of societies newly registered under UK's Co-operative and Community Benefit Societies Act 2014 in a given year. Source of data: own database building on [38]. 
Nonetheless, complexity of planning and the lack of finance have been mentioned as inhibiting smaller scales of generation and the growth of community-led schemes $[63,66-68]$ even within the already small scale of the UK FiT [64]. For example, Wales established the Rural Community Energy Fund to provide feasibility grants, while Scotland has the Community and Renewable Energy Scheme, improving access to capital through preferential loan conditions, and England operates the Rural Community Energy Fund [7,63,69,70]. In addition, crowd-funding and community share offers (issued by cooperatives or community benefit societies) have been increasingly used to finance community energy. Crowd-funding escalated since 2015, because individuals can place investments in Individual Savings Accounts to obtain tax-free returns.

Figure 13 shows a spike in 2015 and a rapid decline in the number of newly founded energy cooperatives thereafter. The likely reason for this phenomenon is the change in both FiT and direct policy support to community energy. In 2014, Her Majesty's Treasury announced that both the Enterprise Investment Scheme and the Seed tax relief would be removed from projects that qualify for FiT, RO or the Renewable Heat Incentive [7]. This may have led to a rush in founding energy cooperatives to still benefit from the advantages. Furthermore, in 2016 the FiTs for small-scale installations were drastically reduced and deployment caps introduced, leading to a remarkable reduction in distributed energy installation, in particular solar PV [65].

In addition to data on the incorporation (and termination) years of initiatives and their geographical location, our database comprises further details on a subset of entries. 104 cooperatives $(33 \%)$ provide details on the size of renewable energy installations. They range between a modest solar roof-top installation of $8 \mathrm{~kW}$ to $16,300 \mathrm{~kW}$ large wind farms. It is interesting to note that hydro power installations are limited by law to $100 \mathrm{~kW}$. Furthermore, the preferred choice of hydro power technology is the Archimedes screw. The argument put forward by cooperatives using this technology is the intention to use the most fish-friendly turbine. A similar preference was found for hydro power projects in Switzerland [71]. The typical size of installations in the small sub-sample is around $200 \mathrm{~kW}$, mainly being larger solar panels. 32 cooperatives (i.e., $10 \%$ ) also provided information on the number of members, which ranges between 49 to 2260 spiking at around 300 and 700-800 members. Again, in view of the small sample size, this can only serve as an indication of the size of cooperatives. 49 cooperatives (i.e., $15 \%$ ) published information about the funds raised in order to realize their project. The amounts range from 62,000-3,700,000 GBP concentrating at around 800,000 GBP.

Contrary to the stark decline in the number of energy cooperatives as observed in Denmark, the cancellation rate is comparably small among British energy communities. Out of the 315 initiatives, only 62 (i.e., $20 \%$ ) have been terminated as of today. Figure 14 shows the number of cooperatives terminated in a given year. A systematic pattern is not obvious from the figure. Instead, the number of closed cooperatives was similar over the years. It can be inferred that changes in the governmental support schemes did not affect the decision to terminate a cooperative, as it has affected the decision to establish one. For 13 of 62 terminated initiatives (i.e., 21\%), details about the reasons to terminate activities are available online. The reasons vary from public acceptance issues (Cardigan Community Energy, Easterley Wind Energy, Devon Community Wind Co-operative), organizational and technical barriers (Kingston Community Energy Limited, Bridport Energy Services), problems to raise enough funds (Abergavenny Community Energy, Mapledurham Community Energy Limited), underestimated demand (Wallingford Community Energy Limited), financial risks due to complexity of planning (Abingdon Hydro), financial problems (Abindgon Hydro, Dove Valley Eco Power Limited), disagreement on purpose or missing focus (Bude Community Power Limited, Wembrook Energy Limited), to changes to other legal forms (Ongarhill Wind Energy Co-operative).

The analysis of the sample from the United Kingdom shows that energy cooperatives registered under the specific act played a role in fostering the introduction of distributed renewable energy in the past years. Therefore, as termination rates are comparably low, future opportunities exist. By mid 2018, the total contribution in terms of installed distributed renewable energy can be estimated from our database to amount to around $150 \mathrm{MW}$. This is a rough estimate derived by information available from 
a third of the cooperatives. However, in view of the tendency that mostly larger cooperatives publish such data, we expect this to be a reasonable lower bound. Indeed, it is in the range of data published by Berka and Creamer [20]. The authors report an installed operational capacity of $105 \mathrm{MW}$ for projects run by energy cooperatives and energy trusts in 2014. Bauwens et al. [7] emphasizes that only $0.3 \%$ of UK's generated electricity does not originate from one of the six large utilities. With $303 \mathrm{TWh}$ of electricity produced in 2016, this corresponds to a capacity of $104 \mathrm{MW}$. This is again of similar size to our estimate.
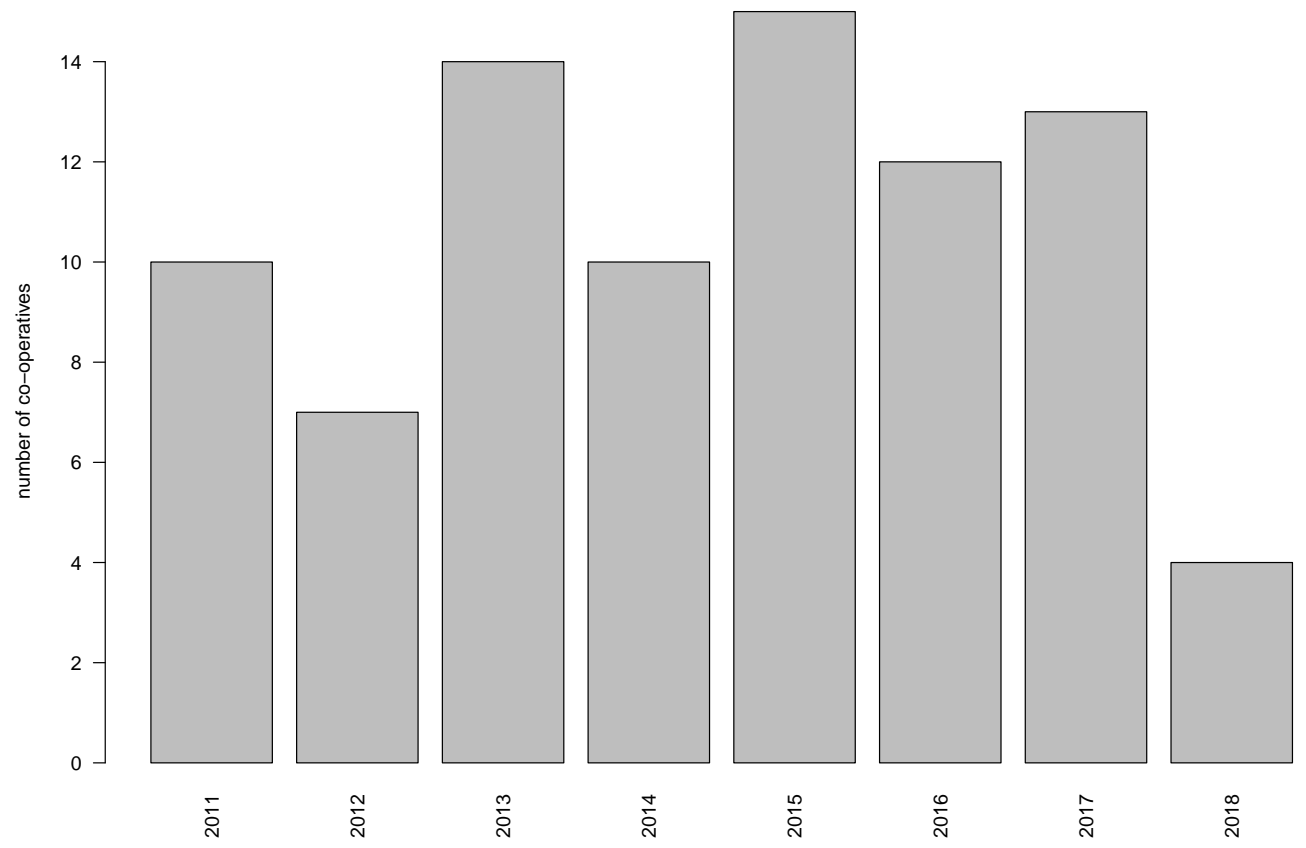

Figure 14. Number of terminated societies registered under UK's Co-operative and Community Benefit Societies Act 2014 in a given year. Source of data: own database building on [38].

\subsection{Austria}

Austria's electricity system is traditionally based on hydro power. In 1970, around $75 \%$ of domestic generation came from hydro power plants. Energy cooperatives were important enablers in rural areas. Our database of Austria contains 9 cooperatives founded during these years and still exist today. The remaining $25 \%$ of domestic power generation was supplied by thermal power plants powered by gas, brown coal and oil. Today, hydro power has a share of $36.5 \%$ among the renewable energy sources. Similar to other EU countries, the environmental movement in the 1980s and early 1990s was an important positive cultural factor. These groups favored wind and solar energy despite the announcement of the Austrian government to disregard the development of wind energy due to sub-optimal wind yields in the country [24].

However, the engagement of communities led to a notable increase in wind power from around $200-600 \mathrm{~kW}$ in the mid 1990s to currently around $1000 \mathrm{MW}$ [72]. Experts estimate that around $80 \%$ of installed wind power capacity in the mid-1990s in Austria were owned by them. In 2010, collective citizen ownership of wind farms still accounted for around $40-50 \%$ of total installed capacity [73]. Most of the community initiatives active in the wind industry are organized as shareholder societies, or they are collaborating with existing utilities. This particular form is known as the citizen power plant ("Bürgerkraftwerk"). Still, wind energy only makes up $4.8 \%$ of renewable energies in Austria.

The second most important renewable fuel after hydro power (having a share of $36.5 \%$ ) is wood with 29.6\% [74]. With Austria being rich in forest land, the country has one of the highest shares for biomass in Europe. This was achieved by a considerable ramping up of biomass-based district 
heating in the 1990s and 2000s. For example, the number of installed plants increased four-fold from 1999 to 2010 [75]. 45\% of the overall district heating output were supplied by these plants [74], and cooperatives were an important actor in the scaling up. In 2010, 66 percent of the plants were run by farmers' cooperatives [76]. The role of district heating is likely to further increase in the future. In its Renewable Energy Action Plan submitted to the European Commission, Austria plans to increase district heating by a factor of five. The target is to enable $175 \mathrm{PJ}$ of district heating.

Seiwald [77] provides a thorough review about historic developments in the upscaling of district heating. The developments coincide with the evolution in the number of energy cooperatives in Austria contained in our database (see Figure 1). $95 \%$ of the registered energy cooperatives are active in the area of district heating, typically run in rural areas. Biomass-based district heating started as a niche in the 1990s by sawmill owners. A ramping up of district heating followed, when farmers seized the opportunity to use residuals from the wood industry to generate additional income. They organized themselves in cooperatives to share financial burdens. These cooperatives were also eligible to receive capital grants and soft loans, allowing to cover of up to $50 \%$ of the investment costs [78]. Additionally, the Green Electricity Law, which was introduced in 2002, guaranteed feed-in tariffs for biomass-based electricity generation. This explains the continuous growth in the number of cooperatives shown in Figure 1. However, by 2005 district heating plants were established in many locations without considering basic network connections and local demand. A corrective measure was the introduction of efficiency targets for district heating plants of $60 \%$ by the Austrian government in 2006. This resulted in a leveling off in the number of newly founded energy cooperatives in the years after, as seen in Figure 1. From our database, we infer that solar PV is only an emerging activity for energy cooperatives in Austria (see also [79]).

\section{Conclusions}

For all countries studied, our statistical evidence confirms the importance energy cooperatives play in the transition toward renewable energy systems. An important finding is that the historic development of the number of energy cooperatives coincides with the development of supportive schemes in the different countries. Our quantitative analysis thus confirms the qualitative findings of the eleven cross-country studies briefly summarized in Section 2. One of the most important contributing factors to the successful establishment of energy cooperatives is the financial support schemes. In particular, guaranteed feed-in tariffs proved to be most effective. In all countries studied, a removal of the supportive schemes caused a remarkable downturn (or at least slowing down) in the founding of new energy cooperatives. Statistical evidence shows how drastic these developments are. Having over 900 energy cooperatives in its peak time, Denmark has meanwhile lost $88 \%$ of the energy cooperatives. In Germany, these developments are less pronounced but the yearly number of newly founded energy cooperatives is continuing to drop. Having access to membership and data on financial shares, we were further able to show, that the quantities react much slower.

We find that the fields of activities of energy cooperatives largely align with the national energy system profiles: wind energy dominates the field of activities for cooperatives in Denmark, biomass-based district heating is most important for cooperatives in forest-rich Austria, while Germany has cooperatives active in many different fields reflecting its diverse energy landscape. The same holds true for the United Kingdom. At the same time, since the investment costs for solar PV are particularly low in recent years, a higher number of cooperatives are engaged in this particular technology (regardless of the country profiles). As a reaction to the removal or tightening up of the incentives schemes, energy cooperatives responded with diversifying their portfolio or increasing the numbers of shares and members, as an alternative to completely terminating all activities. However, there are only very few examples of energy cooperatives with members beyond several thousand. Most energy cooperatives keep their field of activities in the region. This makes them vulnerable to legislative changes that target the optimization of the energy system from the perspective of the national level, shrinking leverage possibilities to adjust. Most importantly, energy cooperatives will 
have to face fierce competition when corporate actors finally enter the new promising markets, which were only opened by pioneering cooperatives. Larger energy cooperatives may provide a solution to this dilemma. Yet, it is important to keep the minimum financial engagement low enough to ensure the participation of diverse social groups. This also supports the local acceptance for the necessity to transition to low carbon energy systems [80,81]. A stronger tie to social opinion can also break the dominant position of established actors and counteract a revival of non-renewable energies [82].

While we acknowledge that our statistical analysis is far from being a complete account of activities of energy cooperatives across Europe, we provide a lower estimate justified by analyzing focal countries and well-covered forms of cooperative action in Denmark, Germany, Great Britain and Austria. Furthermore, we shed light into current shortages of systematic reporting and how to design aggregate accounting schemes in the future. Our empirical analysis clearly confirms such a need of systematically measuring the contribution by these important non-commercial actors. The lack of data can be eliminated through collaborative efforts, the establishment of an open source database that is shared within the research community and through the development of a sound method able to fill data gaps with proper estimates. The most promising indicators able to capture the contribution by energy cooperatives (and other forms of decentralized collective and individual action) are: the number of people involved in these organizations, the number of associations founded in different legal forms, the number of finances mobilized, the number of jobs or off-spin companies created, the amount of energy services provided (including the amount of energy saved). We suggest to lend from the idea of accounting for ecosystem services [83] to account for social system services.

Author Contributions: Conceptualization, methodology, and formal analysis, A.W. and V.J.S.; Investigation, A.W. and V.J.S. for all countries, C.B. and J.S.G. for DNK, J.P.Z. for DEU, C.C. for UK and W.G. for Austria; Data Curation, A.W., J.P.Z. and V.J.S.; Writing-Original Draft Preparation, V.J.S. and A.W.; Writing—Review \& Editing, C.B., C.C., W.G. and J.S.G.; Visualization, A.W.

Funding: This research received no external funding.

Conflicts of Interest: The authors declare no conflict of interest.

\section{References}

1. European Commission, Press Release Data Base. Available online: http://europa.eu/rapid/press-release_ STATEMENT-18-4155_en.htm (accessed on 25 July 2018).

2. Sovacool, B.K. How long will it take? Conceptualizing the temporal dynamics of energy transitions. Energy Res. Soc. Sci. 2016, 13, 202-215. [CrossRef]

3. Grubler, A.; Wilson, C.; Nemet, G. Apples, oranges, and consistent comparisons of the temporal dynamics of energy transitions. Energy Res. Soc. Sci. 2016, 22, 18-25. [CrossRef]

4. Smil, V. Examining energy transitions: A dozen insights based on performance. Energy Res. Soc. Sci. 2016, 22, 194-197. [CrossRef]

5. Sovacool, B.K.; Geels, F.W. Further reflections on the temporality of energy transitions: A response to critics. Energy Res. Soc. Sci. 2016, 22, 232-237. [CrossRef]

6. Fouquet, R. Lessons from energy history for climate policy: Technological change, demand and economic development. Energy Res. Soc. Sci. 2016, 22, 79-93. [CrossRef]

7. Bauwens, T.; Gotchev, B.; Holstenkamp, L. What drives the development of community energy in Europe? The case of wind power cooperatives. Energy Res. Soc. Sci. 2016, 13, 136-147. [CrossRef]

8. Huybrechts, B.; Mertens, S. The relevance of the cooperative model in the field of renewable energy. Ann. Public Coop. Econ. 2014, 85, 193-212. [CrossRef]

9. Tarhan, M.D. Renewable Energy Cooperatives: A Review of Demonstrated Impacts and Limitations. J. Entrepr. Organ. Divers. 2015, 4, 104-120. [CrossRef]

10. Holstenkamp, L.; Radtke, J. Handbuch Energiewende und Partizipation; Springer: Wiesbaden, Germany, 2018.

11. Viardot, E. The role of cooperatives in overcoming the barriers to adoption of renewable energy. Energy Policy 2013, 63, 756-764. [CrossRef] 
12. Brummer, V. Community energy-Benefits and barriers: A comparative literature review of Community Energy in the UK, Germany and the USA, the benefits it provides for society and the barriers it faces. Renew. Sustain. Energy Rev. 2018, 94, 187-196. [CrossRef]

13. Becker, S.; Kunze, C.; Vancea, M. Community energy and social entrepreneurship: Addressing purpose, organisation and embeddedness of renewable energy projects. J. Clean. Prod. 2017, 147, 25-36. [CrossRef]

14. Debor, S. Multiplying mighty Davids? In The Influence of Energy Cooperatives on Germany's Energy Transition; Springer: Heidelberg, Germany, 2018.

15. Mey, F.; Diesendorf, M. Who owns an energy transition? Strategic action fields and community wind energy in Denmark. Energy Res. Soc. Sci. 2018, 35, 108-117. [CrossRef]

16. Hvelplund, F.; Østergaard, P.A.; Meyer, N.I. Incentives and barriers for wind power expansion and system integration in Denmark. Energy Policy 2017, 107, 537-584. [CrossRef]

17. Bauwens, T.; Defourny, J. Social capital and mutual versus public benefit: The case of renewable energy cooperatives. Ann. Public Coop. Econ. 2017, 88, 203-2032. [CrossRef]

18. Bohnerth, J.C. Energy Cooperatives in Denmark, Germany and Sweden-A Transaction Cost Approach. Master's Thesis, Uppsala University, Uppsala, Sweden, 11 June 2015.

19. Kooij, H.-J.; Oteman, M.; Veenman, S.; Sperling, K.; Magnusson, D.; Palm, J.; Hvelplund, F. Between grassroots and treetops: Community power and institutional dependence in the renewable energy sector in Denmark, Sweden and the Netherlands. Energy Res. Soc. Sci. 2018, 37, 52-64. [CrossRef]

20. Berka, A.L.; Creamer, E. Taking stock of the local impacts of community owner renewable energy: A review and research agenda. Renew. Sustain. Energy Rev. 2018, 82, 3400-3419. [CrossRef]

21. Korjonen-Kuusipuro, K.; Hujala, M.; Pätäri, S.; Bergman, J-P.; Olkkonen, L. The emergence and diffusion of grassroots energy innovations: Building an interdisciplinary approach. J. Clean. Prod. 2017, 140, 1156-1164. [CrossRef]

22. Heras-Saizarbitoria, I.; Sáez, L.; Allur, E.; Morandeira, J. The emergence of renewable energy cooperatives in Spain: A review. Renew. Sustain. Energy Rev. 2018, 94, 1036-1043. [CrossRef]

23. Magnani, N.; Osti, G. Does civil society matter ? Challenges and strategies of grassroots initiatives in Italy's energy transition. Energy Res. Soc. Sci. 2016, 13, 148. [CrossRef]

24. Schreuer, A. The establishment of citizen power plants in Austria: A process of empowerment? Energy Res. Soc. Sci. 2016, 13, 126-135. [CrossRef]

25. Schreuer, A. Bürgerkraftwerke in Österreich: Ein Phänomen mit vielen Gesichtern. In Handbuch Energiewende und Partizipation; Holstenkamp, L., Radtke, J., Eds.; Springer: Wiesbaden, Germany, 2018.

26. Mignon, I.; Rüdinger, A. The impact of systemic factors on the deployment of cooperative projects within renewable electricity production-An international comparison. Renew. Sustain. Energy Rev. 2016, 65, 478-488. [CrossRef]

27. Oteman, M.; Kooij, H.-J.; Wiering, M.A. Pioneering renewable energy in an economic energy policy system: The history and development of dutch grassroots initiatives. Sustainability 2017, 9, 550. [CrossRef]

28. Curtin, J.; McInerney, C. How can financial incentives promote local ownership of onshore wind and solar projects? Case study evidence from Germany, Denmark, the UK and Ontario. Local Econ. 2018, 33, 40-61. [CrossRef]

29. Oteman, M.; Wiering, M.; Helderman, J.-K. The institutional space of community initiatives for renewable energy: a comparative case study of the Netherlands, Germany and Denmark. Energy Sustain. Soc. 2014, 4, 14. [CrossRef]

30. Hoicka, C.E.; MacArthur, J.L. From tip to toes: Mapping community energy models in Canada and New Zealand. Energy Policy 2018, 121, 162-174. [CrossRef]

31. Dóci, G.; Gotchev, B. When energy policy meets community: Rethinking risk perceptions of renewable energy in Germany and the Netherlands. Energy Res. Soc. Sci. 2016, 22, 26-35. [CrossRef]

32. Compass Verlag GmbH. Available online: https: / / firmeninfo.at (accessed on 29 June 2018).

33. Firmen ABC Marketing GmbH. Available online: https:/ / firmenabc.at (accessed on 29 June 2018).

34. HEROLD Business Data GmbH. Available online: https:/ / www.herold.at (accessed on 29 June 2018).

35. Common Register Portal of the German Federal States, Handelsregister.de. Available online: https://www. handelsregister.de (accessed on 29 June 2018).

36. Bundesanzeiger Verlag, Company Register. Available online: https://www.unternehmensregister.de (accessed on 29 June 2018). 
37. Danish Business Authority, Virkdata. Available online: https://datacvr.virk.dk/data (accessed on 29 June 2018).

38. Financial Conduct Authority, Mutuals Public Register. Available online: https://mutuals.fsa.gov.uk/Search. aspx (accessed on 29 June 2018).

39. The Co-Operative Economy. Available online: https://www.uk.coop/open-data (accessed on 29 June 2018).

40. Rüdiger, M. The 1973 oil crisis and the designing of a Danish energy policy. Hist. Soc. Res. 2014, 39, 94-112. [CrossRef]

41. Danish Energy Agency, Energistyrelsen. Stamdataregister for Vindkraftanlæg. Available online: https://ens. $\mathrm{dk}$ /service/statistik-data-noegletal-og-kort/data-oversigt-over-energisektoren (accessed on 29 June 2018).

42. Krohn, S. Danish Wind Turbines: An Industrial Success Story; Danish Wind Association: Copenhagen, Denmark, 2002. Available online: http:/ / www.ingdemurtas.it/wp-content/uploads/eolico/normativa-danimarca /Danish_Wind_Turbine_Industry-an_industrial_succes_story.pdf (accessed on 30 July 2018).

43. Hvelplund, F. Renewable energy and the need for local energy markets. Energy 2006, 31, $2293-2302$. [CrossRef]

44. Farrell, J. Feed-In Tariffs in America: Driving the Economy with Renewable Energy Policy that Works; The New Rules Project: Minneapolis, MN, USA, 2009. Available online: http:/ /www.ourenergypolicy.org/wp-conte nt/uploads/2013/08/feed-in-tariffs-in-america.pdf (accessed on 30 July 2018).

45. Bolinger, M. Community Wind Power Ownership Schemes in Europe and their Relevance to the United States; Environmental Energy Technologies Division, Lawrence Berkeley National Laboratory: Berkeley, CA, USA, 2001.

46. Orcana, C.; Van Siclen, S.; Phillips, B.J.; Varley, C. OECD Country Studies Denmark—Regulatory Reform in Electricity 1999; OECD Competition Law \& Policy Devision: Paris, France, 1999. Available online: https:/ / www.oecd.org/regreform/sectors/2497351.pdf (accessed on 30 July 2018).

47. Moné, C.; Stehly, T.; Maples, B.; Settle, E. 2014 Cost of Wind Energy Review; National Renewable Energy Laboratory: Golden, CO, USA, 2014. Available online: https:/ /www.nrel.gov/docs/fy16osti/64281.pdf (accessed on 30 July 2018).

48. Skotte, H. Cooperatives-Local and Democratic Ownership of Wind Turbines in Green Thinking in Denmark; Energynet.dk: Fredericia, Denmark, 2010.

49. Olesen, G.B.; Maegaard, P.; Kruse, J. Danish Experience in Wind Energy_Local Financing; Comite de Liaison Energies Renouvelables: Montreuil, France, 2002.

50. Johansen, K.; Emborg, J. Wind farm acceptance for sale? Evidence from the Danish wind farm co-ownership scheme. Energy Policy 2018, 117, 413-422. [CrossRef]

51. Danish Energy Agency (DEA). Energy Policy Toolkit: Physical Planning of Wind Power-Experiences from Denmark; Danish Energy Agency: Copenhagen, Denmark, 2015; ISBN 978-87-93071-98-8 E.

52. Sperling, K.; Hvelplund, F.; Mathiesen, B.V. Evaluation of wind power planning in Denmark-Towards an integrated perspective. Energy 2010, 35, 5443-5454. [CrossRef]

53. Möller, B. Spatial analyses of emerging and fading wind energy landscapes in Denmark. Land Use Policy 2010, 27, 233-241. [CrossRef]

54. Danish Ministry for Energy, Utilities and Climate. Danish Energy Agency National Renewable Energy Action Plan (NREAP); Danish Ministry for Energy, Utilities and Climate: Copenhagen, Denmark, 2010. Available online: https://www.iea.org/policiesandmeasures/pams/denmark/name-39469-en.php (accessed on 31 July 2018).

55. Anshelm, J.; Haikola, S. Power production and environmental opinions-Environmentally motivated resistance to wind power in Sweden. Renew. Sustain. Energy Rev. 2016, 57, 1545-1555. [CrossRef]

56. Müller, J.R.; Holstenkamp, L. Zum Stand von Energiegenossenschaften in Deutschland, Aktualisierter Überblick über Zahlen und Entwicklungen (zum 31.12.2014). Available online: https://www.leuphana.de/fil eadmin/user_upload/Forschungseinrichtungen/professuren/finanzierung-finanzwirtschaft/files / Arbei tspapiere/wpbl20_energiegenossenschaften2014_final.pdf (accessed on 26 July 2018).

57. Yildiz, Ö.; Rommel, J.; Debor, S.; Holstenkamp, L.; Mey, F.; Müller, J.R.; Radtke, J.; Rognli, J. Renewable energy cooperatives as gatekeepers or facilitators? Recent developments in Germany and a multidisciplinary research agenda. Energy Res. Soc. Sci. 2015, 6, 59-73. [CrossRef]

58. Klagge, B.; Meister, T. Energy cooperatives in Germany-An example of successful alternative economies? Local Environ. 2018, 23, 697-716. [CrossRef] 
59. Trend:research and Leuphana Universität Lüneburg, Definition und Marktanalyse von Bürgerenergie in Deutschland Im Auftrag der Initiative "Die Wende-Energie in Bürgerhand" und der Agentur für Erneuerbare Energien, Bremen/Lüneburg, Deutschland, 2013. Available online: http:/ / www.unendlich-viel-energie.de/ media/file/198.trendresearch_Definition_und_Marktanalyse_von_Buergerenergie_in_Deutschland_okt13 .pdf (accessed on 27 July 2018).

60. Holstenkamp, L. Aufstieg und Niedergang von Elektrizitätsgenossenschaften in Deutschland, Arbeitspapierreihe Wirtschaft \& Recht, Nr. 22. Available online: http:/ /www.leuphana.de/businessandlaw (accessed on 30 June 2018).

61. DGRV DIE Genossenschaften. Jahresumfrage zum 31.12.2015. Available online: http://www.dgrv.de/de/d ienstleistungen/energiegenossenschaften/jahresumfrage.html (accessed on 30 June 2018).

62. Legislation.gov.uk: Co-Operative and Community Benefit Societies Act 2014. Available online: https: / / www.legislation.gov.uk/ukpga/2014/14/contents (accessed on 30 June 2018).

63. Hanna, R. Community Renewables Innovation Lab. Energy Transition Platform Policy Briefing. November 2017; Graham Institute: London, UK, 2017.

64. Nolden, C. Governing community energy-Feed-in tariffs and the development of community wind energy schemes in the United Kingdom and Germany. Energy Policy 2013, 63, 543-552. [CrossRef]

65. Pearce P.; Slade, R. Feed-in tariffs for solar microgeneration: Policy evaluation and capacity projections using a realistic agent-based model. Energy Policy 2018, 116, 95-111. [CrossRef]

66. Phimister, E.; Roberts, D. The Role of Ownership in Determining the Rural Economic Benefits of On-shore Wind Farms. J. Agric. Econ. 2012, 63, 331-360. [CrossRef]

67. Seyfang, G.; Hielscher, S.; Hargreaves, T.; Martiskainen, M.; Smith, A. A grassroots sustainable energy niche? Reflections on community energy in the UK. Environ. Innov. Soc. Trans. 2014, 13, 21-44. [CrossRef]

68. Seyfang, G.; Park, J.J.; Smith, A. A thousand flowers blooming? An examination of community energy in the UK. Energy Policy 2013, 61, 977-989. [CrossRef]

69. Hall, S.; Foxon, T.J.; Bolton, R. Financing the civic energy sector: How financial institutions affect ownership models in Germany and the United Kingdom. Energy Res. Soc. Sci. 2016, 12, 5-15. [CrossRef]

70. Scottish Government Community Energy Policy Statement-September 2015. Available online: http://ww w.gov.scot/Resource/0048/00485122.pdf (accessed on 4 April 2017).

71. Tabi, A.; Wüstenhagen, R. Keep it local and fish-friendly: Social acceptance of hydropower projects in Switzerland. Renew. Sustain. Energy Rev. 2017, 68, 763-773. [CrossRef]

72. Windkraft in Österreich. 2014: Press Conference Slides; Windkraft in Österreich: St. Pölten, Austria, 9 January 2014.

73. Schreuer, A. Energy Cooperatives and Local Ownership in the Field of Renewable Energy-Country Cases Austria and Germany; WU Vienna University of Economics and Business: Vienna, Austria, 2012.

74. Statistics Austria. Available online: http:/ / www.statistic.at (accessed on 26 July 2018).

75. Meyerhofer Burger, C. Erfolgsfaktoren für einen Wirtschaftlichen Anlagenbetrieb-Vom Rohstoff bis zum Wärmeverkauf. Tagungsband 16; Biomassetag, Österreichischer Biomasseverband: Wien, Österreich, 2011.

76. International Labour Office Cooperatives Unit (COOP). Providing Clean Energy and Energy Access through Cooperatives; International Labour Organization: Geneva, Switzerland, 2013. Available online: http: / / www.ilo.org/global/topics/green-jobs/publications/WCMS_233199/lang--en/index.htm (accessed on 31 July 2018).

77. Seiwald, M. The (up) Scaling of Renewable Energy Technologies: Experiences from the Austrian Biomass District Heating Niche. Moravian Geogr. Rep. 2014, 22, 44-54. [CrossRef]

78. Madlener, R. Innovation diffusion, public policy, and local initiative: The case of wood-fueled district heating systems in Austria. Energy Policy 2007, 35, 1992-2008. [CrossRef]

79. Reinsberger, K.; Posch, A. Bottom-up Initiatives for Photovoltaic: Incentives and Barriers. J. Sustain. Dev. Energy Water Environ. Syst. 2014, 2, 108-117. [CrossRef]

80. Musall, F.D.; Kuik, O. Local acceptance of renewable energy-A case study from southeast Germany. Energy Policy 2011, 39, 3252-3260. [CrossRef]

81. Langer, K.; Decker, T.; Roosen, J.; Menrad, K. Factors influencing citizens' acceptance and non-acceptance of wind energy in Germany. J. Clean. Prod. 2018, 175, 133-144. [CrossRef] 
82. Gabaldón-Estevan, D.; Peñalvo-López, E.; Solar, D.A. The spanish turn against Renewable Energy Development. Sustainability 2018, 10, 1208. [CrossRef]

83. Costanza, R.; de Groot, R.; Braat, L.; Kubiszewski, I.; Fioramonti, L.; Sutton, P.; Farber, S.; Grasso, M. Twenty years of ecosystem services: How far have we come and how far do we still need to go ? Ecosyst. Serv. 2017, 28, 1. [CrossRef]

(C) 2018 by the authors. Licensee MDPI, Basel, Switzerland. This article is an open access article distributed under the terms and conditions of the Creative Commons Attribution (CC BY) license (http://creativecommons.org/licenses/by/4.0/). 